\title{
구천응원뇌성보화천존(九天應元雷聲普化天尊) 신앙 연구
}

\section{리웬구어(李遠國)}

중국사천성 사회과학원 · 연구원

I. 뇌법 신앙에서의 구진천존(九宸天尊) III. 보화천존신앙의 과의(科儀)방법

II. 구진고진(九宸高真)과 뇌성보화천존 $\mathrm{IV}$. 한국의 보화천존신앙

뇌법(雷法)은 도교의 중요한 법술로서 내단(內丹)을 근본으로 하 여 부(符)와 주문을 함께 사용한다. 뇌법은 또한 도교의 전통적인 부록(符籙), 주술(呪術), 지결(指訣), 우보(禹步), 기공(氣功), 존신 (存神) 및 내단술(内丹术)은 물론 유학의 수지심법(修持心法), 불교 의 선학, 밀교의 진언 밀주 수련법(眞言密呪修鍊法) 등을 포함한 다.

당송(唐宋)이래 엽법선(葉法善), 풍거치(豐去奢), 등자양(鄧紫陽), 호혜초(胡惠超), 엽천운(葉千韶), 왕자화(汪子華), 적법언(翟法言), 서허적(舒虛寂), 담자소(譚紫霄) 등의 수준 높은 도사들이 당나라 때 뇌법을 창도하였다. 이에 뒤이어 북송의 임영소(林靈素), 왕문 경(王文卿), 장계선(張繼先) 등은 신소파(神霄派)를 개창하였다. 북 송 시기에는 높은 경지의 도사들이 이끄는 가운데 뇌신(雷神) 신 앙을 핵심으로 하는 뇌법이 매우 흥하였으며, 이는 또한 도교 법 문(法門)을 대표하는 영역이 되었다. 즉 신소(神霄), 풍악(豐岳), 청 
미(清微), 천심(天心), 정일(正一), 상청(上清), 영보(靈寶), 정명(淨 明) 등으로 불리는 뇌법이 사회에 유행하면서 세인들이 이에 주목 하게 되었으므로 이는 당시 사회적으로 큰 영향을 끼쳤다. 이와 관련하여 명대(明代)의 장우초(張宇初)는 『현천집』(峴泉集) 제 1 권 에서 이렇게 말하고 있다. “신소 뇌정파(雷霆派)의 시조는 옥청진 왕(玉清真王)인데, 이후 화사왕진군(火師汪真君)이 신소파의 사상 을 널리 알렸다. 또한 이에 뒤이어 왕문경(王文卿), 장허정(張虛 靖), 살수견(薩守堅) 등에게로 그 맥이 전수되었고, 다시 임영소(林 靈素), 서신옹(徐神永), 유혼강(劉混康), 뇌묵암(雷默庵), 만오뇌(萬 五雷), 방빈악(方貧樂), 등철애(鄧鐵崖), 막월정(莫月鼎)으로 도파의 맥이 이어졌다"1)라 하였다. 신흥도파가 분분히 일어나면서 각종 뇌법이 천하에 성행하게 되었고, 이로써 도교에는 뇌신 숭배의 신 앙을 중심으로 새로운 신들이 나타나게 되었다.

\section{I . 뇌법 신앙에서의 구진천존(九宸天尊)}

양송(兩宋) 시기 중국 사회는 특히 뇌법이 성행하던 시기로서, 뇌법의 성행은 뇌신 신앙의 내용이 충실해지도록 하는 한편 큰 발 전을 이루도록 하였다. 이로써 풍우뇌전(風雨雷電)을 관장하고 요 사한 마를 굴복시키는 신령들이 출현하게 되었는데, 이러한 신령 들은 여전히 삼청성조(三清聖祖)의 통치하에 있는 것으로 간주되 었다. 삼청성조(三清聖租) 즉 원시천존(元始天尊), 영보천존(靈寶天尊) 그리고 도덕천존(道德天尊)을 받드는 가운데, 영보동화파(靈寶東華派)에서는 사어(四 禦)를, 신소파에서는 구진천존(九宸大尊)을 내세웠다. 구진천존은 곧 조사 (祖師) 옥청진왕장생보명천존(玉清真王長生保命天尊), 종사(宗師) 청

1) 『道藏』, 第33冊, 文物出版社 · 上海書店 · 天津古籍出版社, 1988년 영인본, p.187. 
화구고태일정복천존(青華救苦太一定福天尊), 진사(真師) 구천익산사 명보복천존(九天益算司命保福天尊), 영사(靈師) 응원정적진군주명천 존(應元定籍真君注命天尊), 현사(玄師) 보명비생진군보명천존(保命化 生真君保命天尊), 성사(聖師) 절도총람진군보생천존(節度總監真君保 生天尊), 보사(寶師) 보생진군저상천존(保生真君儲祥天尊), 천사(天 師) 장법주적진군화예천존(掌法主籍真君和豫天尊), 신사(神師) 장령 강명진군길집천존(掌令降命真君吉集天尊)을 말한다. ${ }^{2)}$

구진천존 중에는 신소옥청진왕(霄玉清真王)의 위치가 가장 높다. 도경(道經)에 의하면 옥청진왕은 원시천존(元始天尊)의 동생이다. 이와 관련된 도장의 기록은 다음과 같다.

노군(老君)이 오뇌군(五雷君) 등에게 말씀하셨다. “원시에 부려원시천존(浮黎元始天尊)이 있었고, 그 부인인 옥청신모원 군(玉清神母元君)과의 슬하에, 장자인 옥청원시천존(玉清元始 天尊)이 있었다. 또한 이들의 아홉째 아들은 고상신소옥청진 왕장생대제(高上神霄玉清真王長生大帝)였는데, 그는 오방제위 대제의 수령으로서 구소삼십육천(九霄三十六天), 삼십육천존 (三十六天尊)을 다스리고 통솔하였으며, 음양을 운용하여, 뇌 정을 관리하는 정무를 맡았다.”3)

육조(六朝)시대의 도경인 『상청대동진경』(上清大洞真經)을 고찰 해 보면, 언급되는 신들 중에 고상신소옥청왕(高上神霄玉清王)에 대한 내용이 있는데, 이로 보아 고상신소옥청왕은 『상청대동진경』 에서 처음으로 언급되고 있음을 알 수 있다. 북송(北宋) 휘종(徽 宗) 시기에 신소파 도사들은 고상신소옥청왕을 부상대제(扶桑大帝) 와 결합시켜 새로운 존신을 창조하였다. 『고상신소자서대법』(高上 神霄紫書大法) 서문에 실린 다음 내용은 이를 잘 보여준다.

옥청신모(玉清神母)는 여덟 아들을 낳았다. 장자를 이름하

2）『高上神霄玉清真王紫書大法』, 卷四, 『道藏』, 第28冊, p.596.

3）『紫微玄都雷霆玉經』, 『道藏』, 第 1 冊, p.750. 
여 남극장생대제(南極長生大帝)라 하였는데, 이를 구룡부상일 궁대제(九龍扶桑日宮大帝) 또는 고상신소옥청진왕(高上神霄 玉清真王)이라 부르기도 하였다. 즉 그는 세 개의 이름을 지 닌 하나의 신이다.

세 개의 이름을 지닌 옥청진왕은 금궐에 응신(凝神)하여 있으며, 세간에서 생활하는 일체 중생의 삼재팔난(三災八難)을 돕는다. 또 한 원시상제를 보좌하여 구천의 죄 지은 혼들을 구제하고, 생사의 세계를 왕래하면서 구소보록(九霄寶箓)을 지니고 원시천존에게 간 청하는 일을 맡아 신통의 능력으로 삼계의 일체 중생을 모두 구제 한다. 원시상제는 고상신소옥청진왕장생호명비법(高上神霄玉清真王 長生護命秘法)을 세상에 전하였는데, 그 밀서는 모두 세 권으로 상 권은 만천지금(萬天之禁)에 대해 말하였고, 중권은 신선만년지법(神 仙萬年之法)에 대해 말하였으며, 하권에서는 사람과 귀신을 다스려 국가를 보존하고 가정을 안녕하게 하는 도를 밝혔다.4)

구진천존 중 두 번째 서열에 해당하는 신격은 청화구고태일정복 천존(青華救苦太一定福天尊)인 데, 이를 동화청화대제(東華青華大帝) 라 부르기도 한다. 도교에서 이 신은 지옥 출입이 가능하며, 액을 풀어 주고 복을 내린다고 알려져 있는 태일구고천존(太一救苦天等) 을 가리킨다. 『태일구고호신묘경』(太一救苦護身妙經)의 기록에 의 하면 자비롭고 인자한 태일구고천존은 동방장락세계(東方長樂世 界)에 거하는데 무한한 화신(化身)이 가능하며 그를 부르는 소리에 응하여 천궁, 인간계, 지옥 등을 오가면서 악을 진압하는 무량한 신통력을 지닌 공덕이 무궁한 신이라고 한다.

그러므로 청화구고태일정복천존은 자신을 부르는 소리에 응하여 고통을 풀어주고 상황에 맞추어 사물에 응하는 신이다. 삼계(三界) 의 모든 영(靈)과 중생들이 어려움이나 난관에 봉착하거나, 질병의 괴로움을 겪고 고통 속에 헤맬 때, 그리고 파도가 강하게 일어 물

4)『道藏』, 第28冊, p.557. 
고기와 용이 상처를 입거나 벽력이 치고 풍우가 일어 두려움에 떨 때, 육친과 형제가 서로 화합하지 못하고 반목할 때, 전쟁이 일어 나고 풍우가 순조롭지 않을 때, 사악한 귀신들이 망동하여 해하려 할 때, 태아를 가졌으나 불안하며 분만에 어려움을 겪을 때, 잦은 소송에 휘말리고 억울한 누명을 쓰고 감옥에 가게 되었을 때, 또 한 지옥에 떨어져 다시 소생하기 어려울 때, 존사(存思)의 방법으 로 그 성호(聖號)를 부르면 해탈하여 영계(靈界)의 감옥에서 벗어 나게 된다고 한다.5)

송대(宋代) 이후, 도교에서는 태일구고천존(太一救苦天尊)을 숭 배하는 것이 매우 유행하였으며, 이는 민간에 깊숙이 침투함으로 써 조정(朝廷)의 지지를 받아 '육어'(六禦)의 하나가 되었다. 이와 연관하여 『도문과범 대전집』(道門科範大全集) 24 권에서는 “금관허 무삼청상제(金關虛無三清上帝)는 호천육어진존(昊天六禦宸尊)이다”6) 라 하였다. 즉 원래의 '사어'(四禦)에 남극장생대제옥청진왕(南極長 生大帝玉清真王)과 동극청화태일구고천존(東極青華太一救苦天尊)이 다시 추가되었던 것이다. 구고천존(救苦天尊)의 형상은 많은 변화 가 있어 왔는데, 그 내용은 아래와 같다.

원광(圓光)이 비추이는 가운데 발로 연화(蓮花)를 밟고, 손 에는 버들가지와 맑은 물을 들고 있고, 머리가 아홉 개인 사 자가 좌우에서 시종을 하고 있다.

한 명의 여인으로 화하여 붉은 비단 옷을 입고, 머리를 풀 어 헤치고, 맨 발로 연꽃 위에 서 있다. 원광이 비추이는 가 운데 손에는 금검(金劍)을 들고 있는데, 아홉 머리의 사자가 입에서 불을 뿜으며 구고천존의 형상을 감싸고 있다.7)

앞서 말한 내용으로 볼 때, 태일구고천존은 망혼을 구하며 중생을 구제하는 공덕이 매우 큰 신임을 알 수 있다.

5) 같은 책, 第6冊, p.182.

6) 같은 책, 第31冊, p.812.

7) 같은 책, 第6冊, p.183. 
구진천존 중 세 번째 서열에 해당하는 신은 구천익산사명호생가 한군장인보복천존(九天益算司命好生可韓君丈人保福天尊)으로서 청성장인주릉도명천존(青城丈人朱陵度命天尊)으로도 불리며, 청성 가한궁(青城可韓宮)에 거한다. 주릉도명천존(朱陵度命天尊)에 대한 신앙은 당나라 때부터 시작되었는데, 이와 연관하여 이비(李沘)가 저술한 『구천사자묘비병서』(九天使者廟碑並序)에서는 이렇게 말하 고 있다.

개원(開元) 19년 8월 21일에 황제가 이렇게 명을 내렸다. “청성산(青城山) 장인묘(丈人廟)는 여산(盧山) 사자묘(使者廟) 와 동일한 신을 모시는 곳으로서, 이러한 사당들은 오악(五 獄) 진군묘(真君廟)에 해당한다. 덕행이 높은 도사 다섯 명을 뽑아 사자묘를 관리하게 하려 하며, 또한 소속된 영묘(營廟) 에 관리를 위탁한다. 덕성과 학식을 갖춘 도사들이 사자묘에 서 수행할 수 있도록 하되, 신청자는 자신의 상황과 신청 사 유를 기록하여 올리도록 한다. 조건에 부합된 자에게 사당의 관리를 맡길 것이다. 이에 명을 받은 이들은 사자의 초상을 모실 것이며, 사묘(祠廟)를 중수하고, 상장(上章) 등의 제초의 식을 행할 지니, 사묘의 주변에는 음식을 제공하는 장소를 만드는 등 여러 측면에서 도관의 행사를 돕도록 하라.”8)

이 외에도 구진제사(九宸諸師)가 각자 임무를 담당하여 법교(法教) 를 관장하도록 하였다.

북송 정화연간(政和年間)의 『고상신소옥청진왕자서대법』(高上神 霄玉清真王紫書大法)에는 뇌정존신(雷霆尊神)에 대한 기록이 있다. 휘종(徽宗) 황제는 도교에 대한 신앙심이 매우 깊었으므로 전국적 으로 도교를 활성화시키고자 하였다. 그는 도사인 위한진(魏漢津), 서신옹(徐神穿), 유혼강(劉混康), 장계선(張繼先), 임영소(林靈素), 왕문경(王文卿)을 총애하고 신뢰했으며 신소파 도법을 매우 중시 하였다. 또한 신소만수궁(神霄萬壽宮)을 건립하도록 명하고, 당시

8）『盧山太平興國宮採訪真君事實』, 卷六, 『道藏』, 第32冊, p.683. 
의 수도인 개봉(開封)에 신소녹단(神霄襫壇)을 만들어 신소파의 부 록을 널리 알리고자 하였다. 정화(政和) 7년 (1117년) 2월에 임영 소는 본래 '청화제군'(青華帝君)의 몸인 휘종이 의화전(宣和殿)에 강림하였다고 하였으며, 휘종에게 '제호(帝誥) - 천서(天書) - 운록(雲 錄)'을 진상하였다. 이후 휘종의 명에 의해 도사 이천여 명이 상청 보록궁(上清寶籙宮)에 회집하였으며, 수도의 관리와 백성들은 임영 소가 이끄는 가운데 '신소비록'(神霄秘袮)을 인정하고 받아들이게 되었다. 이에 임영소는 다시 구천비서(九天秘書), 용장봉전(龍章鳳 篆), 구등뇌법(九等雷法)을 옥편으로 집성하여 왕에게 진상하였다. 이후 휘종의 명에 의해 도사 이천 여 명이 상청보록궁(上清寶筷 宮)에 회집한 가운데, 임영소는 청화제군이 의화전에 강림했다는 사실을 이들에게 알렸으며, 수도의 관리와 백성들은 임영소가 이 끄는 바에 따라 신소파의 비밀 부록(符籙)인 '신소비록' (神霄秘錄) 을 인정하고 받아들이게 되었다. 휘종은 뇌서(雷書) 금경(金經) 전 부를 얻어『도장』(道藏)에 수록하고자 하였으나 모두 얻지는 못하 였다. 이에 임영소는 '옥화천존'(玉華天尊)의 이름으로 상제께 이를 고하였다고 하며, 상제가 파견한 옥녀(玉女)의 도장을 얻은 것을 명의(名義)로 하여 신소사교종사인(神霄嗣教宗師印), 도관뇌공인 (都管雷公印) 등을 만들어, 『뇌서』(雷書) 다섯 권과 함께 휘종에게 바치니 이로써 휘종은 뇌서 전집(全集)을 얻게 되었다.

『도인경』(度人經) 제 1 권은 휘종 시기에 신소경실(神霄瓊室)에 비 밀히 소장했던 중요한 경전이라는 이유로 이후 60권으로 증보되었 다. 그 외『고상신소옥청진왕자서대법』(高上神霄玉清真王紫書大法), 『고상신소옥청비록』(高上神霄玉清秘䇰), 『고상신소진왕설오방천중호 생불살송』(高上神霄真王說五方天中好生不殺頌), 『신소동극화당묘제경 과』(神霄東極華堂妙濟經科), 『고상신소진왕장생 대제강생기』(高上神霄 真王長生大帝降生記), 『상청옥서진부조험제기』(上清玉書真符照驗諸 記), 『동사천진강림시현품기』(옹祀天真降臨示現品記) 등의 뇌경이 있다. “신소 내부에 보관했던 삼통사보(三洞四輔)는 고인(古人)들이 
전해 온 관계로 현재에 이르러 이를 볼 수가 있다. 그러나 역사적 으로 전해 오지 못한 금비보경(禁秘寶經)은 천이백 권에 달하는데, 이는 여섯 등급으로 나뉘고, 십이품(十二品)으로 분류되었으며, 다 시 상-중-하권으로 편집되어 동서화당(東西華堂)에 소장하였다 .”라는 기록은 정화(政和), 선화(宣和) 연간에 신소부(神霄府)에서 비밀히 소장하기 위해 편집되어 만들어졌던 신소경(神霄經)이 천여 권 이상임을 설명한다.

전해오는 『고상신소옥청진왕자서대법』(高上神霄玉清真王紫書大法) 12 권은 저자가 미상이다. 내용과 문자로 볼 때, 송나라 때의 신소파 도사가 쓴 것으로 보인다. 전서(소書)의 머리에『고상신소자서대법 서』(高上神霄紫書大法序)가 있는데, 글의 내용에서 고상신소옥청왕 (高上神霄玉清王)이 금궐(金諵)에 응신하여 있다고 기록되어 있다. 또한 “세간의 일체 중생을 긍휼히 여겨, 삼재팔난과 일체의 고난을 겪은 이와 구천의 혼과 일체의 죄 지은 혼들을 구제하고 재앙을 면하도록 한다. 고난을 겪은 무량 중생들을 구하기 위해 주야(書 夜)를 가리지 않고 마차의 바퀴가 굴러가듯 생사를 왕래 한다”라 하였다. 전해 오는 말에 의하면, 신소파 도사가 금궐(金風)에서 원 시상제(元始上帝)를 배알하여 세 권의 『신소진왕비법』(神霄真王秘 法)을 받았다고 한다.10) 이로 볼 때, 본서는 원래 세 권이었으며, 현재 도장에 수록된 세 권은 대략 북송(北宋) 말의 것으로 짐작되 며, 나머지 아홉 권은 남송(南宋) 때 증보된 것임을 알 수 있다. 여기서 주목할 만한 내용은 이렇듯 중요성이 부각된 신소경전(神 霄經典)의 내용에 보화천존(普化天尊)의 성위(聖位)가 없다는 것이 다. 이는 결국 보화천존의 신앙이 당시 아직 발현되지 않았음을 설명하는 것으로서, 이후 남송 시기 백옥섬(白玉蟾)으로 인해 보화 천존에 대한 신앙이 널리 알려지게 되었다.

9)『道藏』, 第32冊, p.638.

10) 같은 책, 第28冊, p.557. 


\section{II. 구진고진(九宸高真)과 뇌성보화천존}

뇌성보화천존에 관한 기록은 『무상구소옥청대범자미현도뇌정옥 경』(無上九霄玉清大梵紫微玄都雷霆玉經)에서 볼 수 있다.11) 경문에 서는 신소옥청진왕장생대제(神霄玉清真王長生大帝)가 뇌법의 전수 자라고 말하며 주로 신소뇌법을 설명하고 있다. 관련 경문에서는 신소옥청진왕이 원상(元象)을 이끌고, 음양을 주관하며, 구소삼십 육천뇌정(九霄三十六天雷霆)을 다스린다고 말한다. 또한 뇌정이란 천지의 추기(樞機)로서 상벌을 주관하며 크게는 생사를 관장하되 작게는 영광됨과 쇠락함을 다스리는데, 뇌정만이 이를 주관할 수 있다고 말한다.12) 이 외에도 경문에서는 뇌정에서 하계(下界)의 국가 안위를 돕고 백성들을 보살피는데, 재해(災害)를 없애고 복을 구하는 일은 모두 뇌정이 관장하는 일이라고 전하고 있다. 경문에 서는 또한 “고상신소옥청진왕장생대제(高上神霄玉清真王長生大帝), 동극청화대제(東極青華大帝), 구천응원뇌성보화천존(九天應元雷聲普 化天尊), 구천뇌조대제(九天雷祖大帝), 상청자미벽옥궁태을대천제(上 清紫微碧玉宮太乙大天帝), 육천동연대제(六天洞淵大帝), 육파천주제 군(六波天主帝君), 가한장인진군(可韓丈人真君), 구천탐방진군(九天 採訪真君)을 일컬어 신소구진(神霄九宸)이라 한다”13)고 전하고 있 다. 이와 연관하여 명대의 주권(朱權)은 이렇게 말한 바 있다. "구 진은 곧 장생대제(長生大帝), 청화대제(青華大帝), 보화천존(普化天 尊), 뇌조대제(雷祖大帝), 태을천제(太乙天帝), 동연대제(洞淵大帝), 육파제군(六波帝君), 가한진군(可韓真君), 탐방진군(採訪真君)을 가 리킨다. 이들은 원시 (元始)의 아홉 가지 기(氣)로 화생(化生)되었

11) 『無上九霄玉清大焚紫微玄都雷霆玉經』，一卷，작자미상，북송(北宋)의 도사(道士) 가 쓴 것으로 추정됨.

12) 『道藏』, 第 1 冊, p.752.

13) 같은 책, 第1冊, p.752. 
으므로 구진상제(九宸上帝)라고도 한다. 구진(九宸)은 하늘을 대신 하여 조화를 행하고 만물을 주재한다.”14)『뇌정옥경』(雷霆玉經)의 구진고진(九宸高真)은 『자서대법』(紫書大法)에서 말하는 구진천존 과 조금 다른데, 이는 송대(宋代) 신소파(神霄派) 신계(神系)를 전 승 받았기 때문이다.

구진고진 중의 장생대제(長生大帝), 청화대제(青華大帝), 장인진군 (丈人真君)은 『고상신소옥청진왕자서대법』(高上神霄玉清真王紫書大法) 에서 볼 수 있는데, 그 외는 모두 새롭게 탄생한 신들이다. 새롭게 나타난 신들 중 뇌조대제(雷祖大帝)는 구천뇌정중궁(九天雷霆中宮) 에 거한다고 하는데, 『태을진뇌벽력대법』(太乙真雷霹靂大法)에서는 주요 법신으로 일컬어져 태을뇌조대제(太乙雷租大帝)라 이르며, 그 얼굴색이 붉은 대추 빛과 같고, 흉악한 얼굴을 하고 있으나 지존

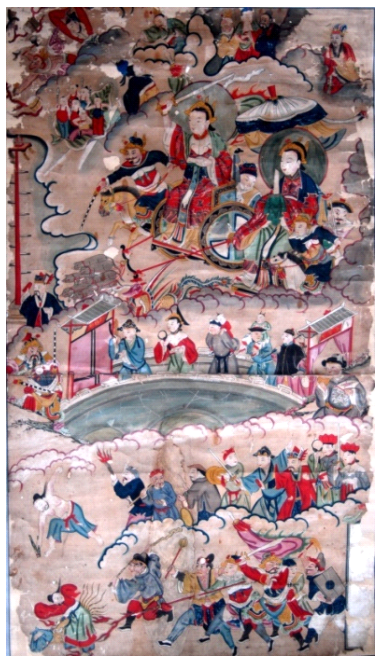

<그림 1> 두모출순도(斗姆出巡圖) [청대 회화, 리웬구어 소장] 지엄하여 감히 범할 수 없다15)라고 기록 되어 있다.

그러나 후대의 도경에서는 뇌조대제를 가리켜 두모(斗母) 또는 천모(天母)라 일 컫고 있다. 이와 관련하여, 『기우심장식』 (新雨心章式)에는 법사(法師)의 주장(奏

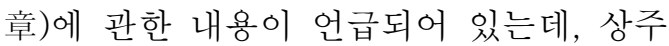
법(上奏法)은 주로 구천뇌조성덕거광천모 마리지천자금묘상황군(九天雷租聖德巨光 天母摩利支天紫金妙相皇君)의 어전(御前) 에서 그리고 일궁태양제군(日宮太陽帝君), 월부태음황군(月府太陰皇君)의 성전(聖前) 에서 행한다고 말하고 있다.16) 두모(斗 母)의 형상은 매우 특이한데 두 개의 팔

14）朱權，『天皇至道太清玉冊』，怣五，『道藏』，第36冊，p.404.

15）『道法會元』，卷一三三，『道藏』，第29冊，p.649.

16）같은 책, 卷九十, 『先天一帒雷法』, 『道藏』, 第29冊, p.375. 
이 있다고 형용되는가 하면 여느 때는 팔이 여덟 개라고 말하기도 한다. 예를 들면, 두모자광천후마리지천대성(斗母紫光天后摩利支天 大聖)은 사두팔비(四頭八臂)로 화신(化身)되었는데, 머리의 정면은 천신(天神)의 모습이나, 머리의 왼편은 돼지의 모습이며, 오른쪽은 귀(鬼)의 형상이고, 또한 머리 뒤쪽은 사자의 모습이다. 여덟 개의 팔을 보면, 두 손으로 각각 일월(日月)을 들고 있고, 또 다른 한 손에는 미늘창을 들고 있는데, 미늘창 위에는 깃발이 꽂혀 있으며, 깃발에는 구천뇌조대제(九天雷祖大帝)라는 글자가 금색으로 새겨 져 있다. 또 다른 손에 검을 들고, 또 한 손에는 도장을, 또 다른 손에는 금줄을, 또 다른 손에는 활을, 그리고 또 다른 손에는 화살 을 들고 있다. 두모자광천후마리지천대성은 이러한 형상을 하고 일곱 마리의 돼지가 끄는 마차를 타고 있다.17)

구천탐방사자(九天探訪使者)인 응원보운묘화진군(應元保運妙化真 君)은 구천진왕(九天真王), 화련진인(火鍊真人), 남상진군(南上真君) 이라 불리기도 한다. 응원보운묘화진군은 비교적 이른 시기에 출현 하였는데, 위진(魏晉)시기에 이미 존재하였다. 『태상삼천정법경』(太 上三天正法經)에서는 구천진왕(九天真王)과 원시천왕(元始天王)은 원 시의 기(氣)에 앞서 출현한 신이라고 하였다. 또한 『남당강현진도기 』(南唐降現真圖記)에서는 진군(真君)은 구원지검(九元之劍)을 갖고 있으며, 오제복마(五帝伏魔)의 인장을 들고 있다 하였다.18) 특히 구천진왕의 인장은 하늘의 귀한 신들을 의미하므로 택렁(宅靈)으 로 분화하여 동천복지(洞天福地)를 돌보고 국가와 가정을 보살피 므로 고관대작들이 구천진왕을 믿어 예를 갖추고 사대부와 백성들 이 구천진왕을 받들면 확연한 효험이 있다고 하였다. 『구천응원뇌 성보화천존옥추경』(九天應元雷聲普化天尊玉樞經)에서는 원래 구천 진왕이 태양구룡황군(太陽九龍皇君)인데 천존의 명으로 구천탐방사 자가 되었으며, 그는 뇌정지도(雷霆之道)를 관할하고 사서(四序)를

17）姚複莊, 『玉樞經錀』, 卷二十注, 『藏外道書』, 第4冊, 巴蜀書, 1994, pp.787-788.

18）『盧山太平興國宮採訪真君事實』, 卷一, 『道藏』, 第32冊, p.662. 
지키고 오행을 통제한다19)라 하였다.

당 - 송(唐·宋)이래로는 강서(江西)의 여산(盧山)에 조정(祖庭)을 두었으며, 구천탐방사자를 숭배하는 풍조가 강남(江南)에 크게 유 행하였다. 당(唐) 현종(玄宗) 때에는 임금이 구천탐방사자의 사당 을 여산(盧山)에 짓도록 명하기도 하였다. 사당 내에는 구천탐방사 자의 상을 중간에 위치하게 하고, 그 좌우 각각에 금동(金童), 옥녀 (玉女), 영관(靈官)을 두고, 육정육갑(六丁六甲)의 상을 두었다. 또 한 사당 내의 양측 벽에는 상청태미이십사위진인(上清太微二十四位 真人)을 그리고, 사당 바깥의 좌측 벽에 십이 계녀(十二溪女)를 그 렸으며, 우측에 구강수제(九江水帝)와 삼강대왕(三江大王)을 그려 넣었다. 이 모두는 오도자(吳道子)의 그림을 모방한 것으로서 그 모습들이 생동감 있는 필치로 잘 묘사되어 있다. 사당 좌측 벽 쪽 에는 삼관대제(三官大帝)를 모셨으며, 또한 오른쪽에는 사성진군 (四聖真君)을 모셔 놓았다.20) 여산에 구천탐방사자의 사묘를 건립 한 이후로 공을 들이면 매우 영험하여 공을 드리는 사람들이 끊이 질 않아 ‘연화회’(蓮花會)가 만들어졌는데, 이후 연화회는 일동회 (日同會)와 함께 풍년을 빌고 돌림병을 막는 기도를 행하였다.21) 이후 역대의 조정에서 구천탐방사자를 더욱 공경하여 받들게 되었 으며, 많은 궁관에서 이를 모시고 신앙하게 됨으로써 구천탐방사 자에 대한 신앙이 지속적으로 이어지게 되었다.22)

다음으로는 구천응원뇌성보화천존(九天應元雷聲普化天尊)에 대 해 언급하려 하는데, 기실 그의 신위는 매우 중요하다. 『구천응원 뇌성보화천존옥추보경』(九天應元雷聲普化天尊玉樞寶經)이 세상에 알 려진 이후, 뇌성보화천존(雷聲普化天尊)은 뇌정을 주재하는 대신(大 神)으로 자리매김하였으며, 신소옥청진왕(神霄玉清真王)의 직권을

19）『道藏』, 第1冊, p.752.

20）『盧山太平興國宮採訪真君事實』, 卷一, 『道藏』, 第32冊, p.663.

21) 같은 책, 卷一, 『道藏』, 第32冊, p.664.

22) 같은 책, 卷三, 『道藏』, 第32冊, p.675. 
대신하는 존재가 되었다.23) 경문(經文)에서는 뇌성보화천존의 법 문(法門)을 선양하기 위한 방책으로 천존의 성호를 부를 것을 권 장한다. 천존이 말씀하시기를 “일체의 중생과 천룡귀신(天龍鬼神) 이 내 이름을 부르면 모두가 액난을 물리칠 수 있게 된다. 마음속 으로 나의 이름을 부르거나 혹은 한 번 소리를 내어 부르거나, 다 섯 일곱 번, 백 번 혹은 천 번을 부르게 되면 내가 시방에 화하여 삼계를 보살필 것이니 나를 부르는 자는 모든 일이 여의(如意)하 게 될 것이다" 24)라고 하였다. 이렇듯 법문을 염송하는 것은 매우 쉽고도 간단하여 누구나 할 수 있었으므로 사회적으로 크게 확대 되었다. 남송(南宋) 건염원년(建炎元年: 1127년)에 오나라 사람인 주거(周舉)가 수도에서 고향으로 돌아오게 되었다. 당시는 전쟁으 로 매우 혼란한 시기여서 도처에서 도적이 들끓었다. 이때 어떤 도사가 이르기를 "당신은 병란에 의해 죽게 될 몸이 분명하나 십 자경(十字經)을 염송하면 죽음을 면하고 원을 풀어 장수하게 될 것이다"라 하였다. 이에 주거가 무릎을 꼻고 가르침을 청하니 도 사가 말하기를 “구천응원뇌성보화천존이 곧 십자경이다"라고 하였 다. 신의 가르침을 얻은 주거는 이후부터 열심히 십자경을 염송하 였는데, 이후 도사가 예언한 바와 같이 강도와 도적을 만나게 되 었다. 이때 그가 구천응원뇌성보화천존을 다 부르기도 전에 뇌성 이 진동하여 도적들이 놀라 도망가게 되었고 주거는 난관을 피할 수 있었다.25) 이러한 기록에서는 '십자경'의 영험함에 대해 논하고 있는데, 이는 또한 『옥추보경』(玉樞寶經)이 북송시대에 탄생한 것 임을 증명하고 있기도 하다.

『옥추보경』은 뇌성보화천존에 대한 신앙을 중심으로 하고 있으 며 뇌성보화천존의 신격, 직무, 권능 등에 대해 상세히 기록하고 있다. 『옥추보경』에서는 뇌성보화천존이 오뢰(五雷)를 관장하고, 군

23)『玉樞寶經』, 一卷, 작자미상, 북송(北宋), 휘종 시기(徽宗 時期)에 발견됨.

24）『道藏』, 第 1 冊, pp.758-759.

25）『盧山太本興國宮採訪真君事實』, 卷七, 『道藏』, 第32冊, p.700. 
생(群生)을 보화(普化)하고, 선악에 대해 상벌을 내린다고 말하고 있으며 뇌법(雷 法)과 지극히 현묘한 도(重玄至道)의 내용 을 설명하고 있다. 즉『옥추보경』에 의하 면, 뇌성보화천존은 구천정명대성(九天貞 明大聖)으로도 불리며 옥소부(玉霄府)를 다 스리고, 삼십육천 내원(三十六天內院)을 관 장한다. 이와 연관하여 삼십육천 내원의 가운데 동서화대(東西華台)가 있고, 현관묘 각(玄官妙閣)이 있으며, 사부육원(四府六 院)이 있다. 사부육원에는 사(司)가 있고,

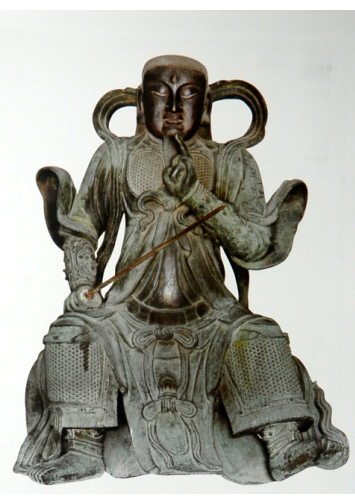

<그림 2>보화천존상 [명대 청동상, 북경 동악묘(東獄廟) 소장] 이는 다시 각 관리부문으로 분리되어 오뢰(五雷)를 맡아 봄으로 그 힘이 삼계에 미침을 설명한다. 이 외에도『옥추보경』에서는 만 약 누군가가 도를 공부하여 성선(成仙)하고자 하거나 조상을 구원 하고자 하거나 삼재를 없애고자 한다면 정일도사(正一道士)에게 명하거나 친우와 함께 도관으로 오거나 혹은 가정 내에서나 단체 에서 물과 꽃을 바치고 경을 한 번, 세 번 혹은 다섯 번 또는 수 십, 수백 번을 외우면 신(神)과 기(氣)가 깨끗하고 상쾌해지며 마 음이 넉넉해지고 본인이 원하는 모든 바에 신의 뜻이 감응하게 될 것이라고 말한다.26)

『옥추보경』의 내용을 좀 더 살펴보면 뇌성보화천존이 삼십 육천 위에 거한다고 말하고 있으며, 손에는 금광여의(金光如意)를 들고 있다고 말하고 있다. 또한 이르기를 뇌성보화천존은 청정심(清靜 心)으로 큰 뜻을 밝히며, 지혜로써 복마(伏魔)를 제압하고, 오뢰(五 雷)를 관장하는데, 삼계와 살아있는 일체 군생과 모든 영(靈)에 그 마음이 미친다고 하였다. 27) 또한 이러한 이유로 그의 은택은 시 방에 미치고, 그 덕은 만리에 뻗치니 만물이 그를 따를 것이며, 간

26）『道藏』, 第1冊, pp.758-789.

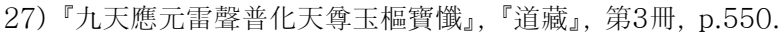


구하는 바가 있어 이를 염원하면 반드시 이에 응감하게 될 것이라 하였다. ${ }^{28)}$

경문에서는 '지도'(至道)와 '기수'(氣數)에 대해 언급하고 있는데, 관련 내용을 살펴보면 다음과 같다. “도는 성(誠)이 본바탕을 이루 어야 하며, 말없이 지켜야 하며, 부드러움을 써야 한다. 도를 행하 는 자는 성을 다하므로 어리석은 듯 보이고, 늘 침묵하므로 말재 주가 없는 듯이 보이며, 부드럽고 온화하므로 서투르고 보잘것없 어 보인다. 그러나 대저 이와 같이 하면, 형체를 잊어버리고, 나를 잊게 되며, 잊음 또한 잊게 된다. 도에 들어 온 자는 그침을 알아 야 하고, 도를 지키는 자는 부지런해야 하며, 도를 쓰는 자는 미약 함을 알아야 한다. 미약함을 알아야만 생의 지혜와 광명을 알 것 이며, 부지런함을 알아야만 지혜가 완전해질 것이며, 그침을 알아 야만 모든 것이 안정을 얻을 것이며, 크게 안정되어야만 완전한 지혜를 얻게 될 것이고, 밝은 지혜를 얻게 되는 것을 도(道)와 일 치를 이루었다고 하는 것이니, 이는 곧 진정한 잊음을 말한다. 오 로지 잊었으나 잊지 않고, 잊었으나 잊은 것이 없으며, 모든 것을 잊지 않은 자라야 도에 이른 것이라 할 수 있다.”29) 사람마다 받 은 기가 다르며, 지혜와 우둔함 그리고 맑음과 탁함의 수(數)가 있 는 것이니, 수계(數系)를 명(命)이라 하고, 기계(氣系)를 천(天)이라 한다. 그러나 도를 공부하는 자가 기수(氣數)에 얽매이거나 천명 (天命)에 얽매이게 된다면, 참된 도를 얻을 수 없다. 경문에서는 또한 재액을 없애고 푸는 방법을 말하였는데, 삼재구액(三災九厄) 을 당했을 때 경문을 염송하거나 마음으로 보화천존(普化天尊)을 염송하게 되면 제신들이 재액을 소멸시킨다고 되어 있다. 또한 경 (經)에 귀명(歸命)하게 되면 장생할 수 있다고도 말한다. 도서(道 書)에 의하면, 뇌성보화천존은 옥청진왕(玉清真王)의 화신(化身)이 다. 『구천응원뇌성보화천존옥추보참』(九天應元雷聲普化天尊玉樞寶

28）『雷霆玉極宥罪法懺』, 『道藏』, 第3冊, p.552.

29）『道藏』，第1冊， p.759. 
懺)에서는 아래와 같이 이르고 있다. "나의 조사(祖師)는 신소(神 霄)에서 오시어 설법한다. 오로지 구천정명(九天貞明) 대성(大聖) 을 공경하니, 옥청진왕(玉清真王)의 화신(化身)으로 시방에 그 형 체를 나타내고, 그 마음이 삼계에 미치며, 중생들을 고뇌로부터 구 제하고 이끈다. 뇌성보화천존은 삼십육천(三十六天)을 주재할 권능 이 있으며, 자비로서 천오백 겁을 운행시키고 변화시킨다." 그러므 로 “구천응원뇌성보화천존은 모든 군생의 아버지이자 모든 영(萬 靈)의 스승이다.”30)

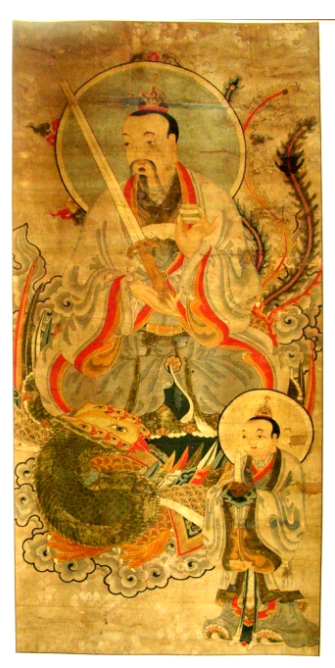

<그림 3> 보화천존상 [청대 회화, 사천원도박물관 소장]

『구천응원뇌성보화천존옥추보경집주』(九 天應元雷聲普化天尊玉樞寶經集注)에서는 뇌성보화천존의 형상에 대해 아래와 같이 언급하고 있다. "천존은 구봉(九鳳)을 탄 채, 손에는 밝게 빛나는 여의주를 들고 있 고, 맑은 바람이 불고 아름다운 구름이 펼 쳐진 곳에 계신다.” 31 ) 여기서의 '구봉'은 곧 머리가 아홉 개인 붉은 빛의 봉황을 말 한다. 현존하는 청대(清代)의 뇌성보화천존 의 화상(畫像)을 보게 되면 뇌성보화천존이 머리가 아홉인 붉은 봉황 위에 앉아 있고, 왼손으로는 삼산결(三山訣)을 행하며 정배 (淨杯)를 들고 있고, 오른손은 배꼽 위에 둔 채 장심(掌心)으로 검을 받치고 있는데, 그 법상은 자비로우면서도 단정하며 장중하다.

『구천응원뇌성보화천존옥추보경집주』하권에서 이르기를 “구천 보화군(九天普化君)은 시방에 그 형상을 나타내며, 머리를 풀고 기 린(麒麟)을 타고 있는데, 맨 발로 겹겹의 얼음 위를 밟고 있다. 손 으로는 구천의 기를 운용하며 바람을 부르고 뇌정을 다스린다. 또

30) 같은 책, 第3冊, pp.549-550.

31) 같은 책, 第2冊, p.573. 
한 그 지혜로써 복마와 정령을 진압하고, 떠도는 혼을 제도하며 중생을 이롭게 한다”라 하였다. 요복장(姚複莊)은 “천존은 밝은 위 엄으로 가득 하며, 천하의 인(仁)으로 화(化)하시고, 머리를 풀어 헤치고 기린(麒麟)을 타고 있다”32)라고 주해하였다.

옆은 명대의 신상을 그린 것으로, 그림의 중앙에는 뇌성보화천존이 있는데, 머리를 푼 상태로 이마를 드러내고, 맨발로 기린 (麒麟)을 타고 있다. 또한 오른손에는 쇠로 된 채찍을 높이 들고 있는데, 이는 "바람을 부르고 뇌정을 다스림”을 상징하는 것이다. 또한 왼손으로는 '결' (訣)을 행하고 있으며, 중지의 끝에서 아홉 가지의 색이 발산되고 있는데, 이는 “손으로 구천의 기를 잡고 있 음”을 뜻하며, 이로써 천존이 뇌정을 다스 림을 의미한다. 여기서의 '구기'(九氣)란 곧 만물의 근원을 뜻한다.

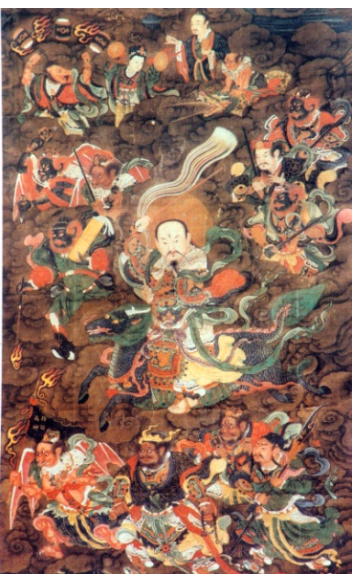

<그림 4>뇌성보화천존상 [명대 회화, 미국인 개인 소장]

뇌성보화천존의 주변에는 뇌부에 속하는 뇌공(雷公), 전모(電母), 우사(雨師), 풍백(風伯)을 비롯한 십대원사(十大元帥)가 자리하고 있다. 십대원사는 모두 매우 특이하면서도 위엄이 있고, 용맹한 모 습을 하고 있어, 제 각각의 이름을 식별하기가 쉽지 않다. 초보적 인 고찰에 의하면, 이들은 등백온원사(鄧伯溫元帥), 신한신원사(辛 漢臣元帥), 장원 백원사(張元伯元帥), 왕선원사(王善元帥), 감생고원 사(監生高元帥), 은교원사(殷郊元帥), 마승원사(馬勝元帥), 구장원사 (苟章元帥), 필환원사(荁環元帥), 관원사(關元帥)인 것으로 보인다. 이러한 신장들은 양송(兩宋) 시대에 출현하였으며, 대다수가 뇌부 의 제신인데, 도서에서는 등백온(鄧伯溫), 신한신(辛漢臣), 장원 백 (張元伯)을 뇌정삼사(雷霆三帥)라 이르고 있다.

32）姚複莊, 『玉樞經錀』, 卷二三, 『藏外道書』, 第 4 冊, p.803. 
백옥섬(白玉蟾)이 말한 바에 따르면, 삼사(三帥)의 연원은 그 역 사가 유구한데, 상고시대의 제왕(帝王)인 복희(伏犧)나 황제(黃帝) 의 후손들이라고 한다. 복희는 두 아들이 있었는데 장자는 남두화 관(南斗火官)으로 불리고, 차남은 욱광(郁光), 즉 등백온(鄧伯溫)으 로 불린다. 황제는 원래 뇌신의 아들로서 신한신(辛漢臣), 장원백 (張元伯)은 황제의 후예들이다.33) 요복장(姚複莊)은 『옥추경약』(玉 樞經錀) 20 권에서 다음과 같이 주해하였다.

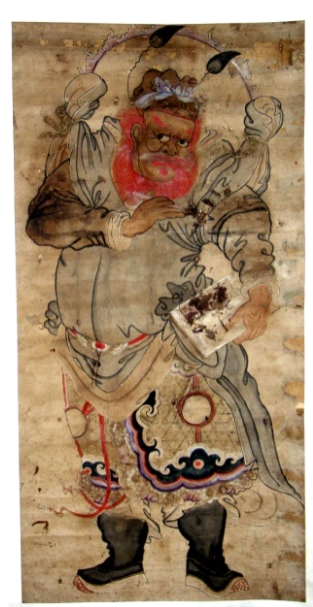

〈그림 5> 등백온(鄧伯溫)상

[명대 회화, 리웬구어 소장]

뇌왕인 등백온(鄧伯溫)은 뿔이 있고, 머리 는 붉으며, 얼굴과 몸은 푸르고, 날개가 있고, 봉황의 발톱을 지녔으며, 세 개의 눈이 있고, 머리에 금 테두리를 두르고 있다. 또한 금실 로 짠 옷을 입고, 치마는 홍색이며, 허리에는 비선대(飛仙帶)를 두르고 있다. 오른손에는 뇌추(雷槌)를 들고 있으며, 왼손에는 뇌찬(雷 鑽)을 들고 있는데 이로써 구천을 운령(運令) 한다. 구천을 장관하고 명령을 내리는 뇌왕인 신한신(辛漢臣)은 철로 된 부리가 있고, 치아 는 은(銀)인데, 허리에 화대(火帶)를 두르고, 천으로 머리를 감싸고 있다. 그는 또한 푸른 도포를 입었으며, 검은 신발을 신고, 왼손에 는 뇌부의 장부를 들고 있고, 오른손에는 화필을 들고 있는데, 신 한신은 관형을 판결한다. 이 외에도 구천을 운행하는 뇌왕인 장원 백(張元伯)은 머리에 혹이 있고, 붉은 머리카락에 푸른 얼굴과 몸 을 하고, 봉황의 부리가 있으며, 날개를 지녔다. 또한 봉황의 발톱 을 지니고, 머리에 금 테두리를 둘렀으며, 푸른 실로 짠 옷을 입 고, 붉은 치마에 비대(飛帶)를 두르고, 오른손에는 뇌부(雷簿)를 들 고, 왼손에는 뇌찬(雷鑽) 혹은 오른손에는 깃발 왼손에는 격문을

33）『道法會元』, 卷八二, 『雷霆三帥心錄』, 『道藏』, 第29冊, pp.328-329. 
들고 있다.34) 이 삼사(三帥)는 뇌정삼부(雷霆三部)를 관장하며 적 시(適時)에 응하여 강세(降世)하므로 매우 강한 위엄을 지니고 있 다.

감생고원사(監生高元帥)는 곧 구천감생대신(九天監生大神)이다. 그는 오른손에는 장검을 들고 왼손에는 소반을 받치고 있는데 그 소반 속에는 어린 아이가 들어 있다. 『문창응화연사묘응경』(文昌應 化延嗣妙應經)에서 말하기를 구천감생고원사(九天監生高元帥)는 신 을 부르고 바람을 제어하며, 훌륭한 후손을 낳게 해준다고 하였다.

은교원사(殷郊元帥)는 상청무춘맹리태세(上清武春猛吏太歲), 지사 맹리 태세(地司猛吏太歲), 지사태세 대위덕신왕(地司太歲大威德神王)으 로도 불린다. 『삼교수신대전』(三教搜神大全) 5권에서는 이렇게 말 하고 있다. 은교원사는 주왕(紂王)의 아들로서, 태어났을 때 육구 (肉球) 속에 아기가 들어 있는 상태였는데, 달기가 그를 해하여 외 딴 곳에 버려지고 말았다. 그러나 까마귀가 해를 가려 주었고, 흰 사슴이 젖을 주어 그를 키웠다. 그러던 중 적신진인(適申真人)이 지나다 이를 발견하여 검(劍)으로 육구를 가르니 그 속에서 아기 가 나왔다. 이에 진인이 그 아기를 수렴(水濂) 동굴로 데려왔고, 하선고(賀仙姑)에게 청하여 그에게 젖을 주고 양육하게 하였다. 적 신진인은 아기의 법명을 금정노(金叮奴)라 하고, 정식 이름을 금나 타(金哪吒)라 지었는데, 교외에 버려진 일이 있었다 하여 유명(乳 名)을 은교(殷郊)라 하였다. 그 아이가 자라 수도하여 득도를 하게 되니, 천기팔보(天妃八寶) 동굴에서 황월(黃鋮)과 금종(金鐘)을 얻 었으며 또한 '현신아장'(㲊神鴉將)을 굴복시켰다. 또한 그는 진인의 명에 응하여 소추산(掃帚山)으로 들어가 십이강인(十二強人)을 정 복하였는데, 십이강인은 곧 흉신(凶神)인 십이상문곡귀고루신(十二 堮門哭鬼骷髅神)을 말한다. 은교원사가 이들을 모두 도륙하여 그 들의 해골을 목에 걸고 오자 진인은 이렇게 말했다. “이 해골은

34）같은 책, 然九八, 『道藏』, 第29冊, p.423. 
적을 징벌할 때 도움을 얻을 수는 있는 것이니 해골을 한 번 두드 리면 귀신이 울게 되므로 적들이 놀라 정신이 혼미해지고 맥이 빠 지게 되어 싸우지 않고 절로 후퇴하리라.” 진인은 은교원사에게 명하여 이를 활용하여 주 무왕(周武王)을 도와 주왕(紂王)을 물리 치게 하였다. 이에 은교원사는 뇌진자(雷震子) 등을 인솔하여 용감 하게 전장을 진두지휘하여, 위엄을 떨치며 적을 물리쳤고, 직접 달 기의 목을 베어 조상과 자신의 원수를 갚았다. 옥제가 은교원사의 효자지덕(孝慈之德)과 요괴를 물리치는 용맹함을 전해 듣고, 그를 지사구천유혁사지덕태세살벌위권은원사(地司九天游奕使至德太歲殺 伐威權殷元帥)에 봉하였다.

그의 형상에 대해서는 "얼굴은 푸르고, 머리를 묶어 목덜미 가운데에서 쪽을 지었 는데, 붉은 귀밑털과 머리카락을 지녔다. 붉은 옷을 입었고, 머리 위에 해골이 있으 며, 목 아래쪽에 아홉 개의 해골이 있고, 왼손에는 금종(金鐘)을 들고 있고, 오른손 에는 황월(黃鋮)을 들고 있으며, 머리가 아 홉인 금우(金牛)를 타고 있다”35)라 전한다. 혹은 “푸른 얼굴 푸른 몸에 금관을 쓰고, 머리는 붉으며, 붉은 도포를 입고, 검은 띠 를 허리에 매고 있으며, 위에 있는 왼손으 로는 해를, 오른손으로는 달을 받치고 있 고, 아래에 있는 오른손으로는 월부(鋮斧) 를 왼손으로는 금종(金鐘)을 들고 있다. 머

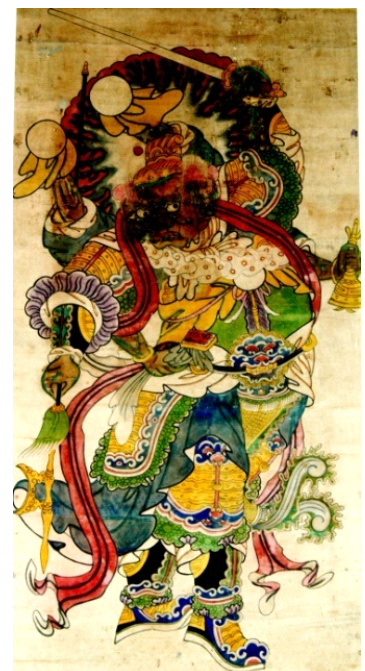

<그림 6>은교(殷郊)상 [청대 회화, 리웬구어 소장] 리 위에는 열 두 개의 해골을 목에 걸고, 오방오색의 구름 중에 있다”36)라 전하기도 한다. 그러나 은교원사의 기본 특징으로는 목 부분과 이마에 해골을 달고 있는 것, 그리고 용맹하고도 노한 모

35) 같은 책, 然三七, 『道藏』, 第29冊, p.7.

36) 같은 책, 卷二四七, 『道藏』, 第30冊, p.521. 
습 등을 들 수 있는데, 이는 도교의호법원사(護法元帥) 의 모습에 서 보기 힘든 매우 특이한 형상이라 하겠다.

좌벌마사구원사(左伐魔使荷元帥), 우벌마사필원사(右伐魔使畢元帥) 는 뇌문(雷門)을 지키는 원사들이다. 삼교원류수신 대전(三教源流搜 神大全)에서는 구원사(荷元帥)를 뇌문포고지신(雷門布鼓之神)이라 하기도 하는데, 필원사(畢元帥)와 함께 오방(五方)의 일을 맡아 지 상과 하늘을 오가며 이승과 저승의 사마(邪魔)와 악귀(惡鬼)를 다 스린다. 또 다른 일설에서는 필원사(畢元帥)는 십이뇌정(十二雷庭) 을 관장하고, 현천상제(玄天上帝)를 보좌하며, 귀신을 부려 돌림병 을 막고, 천지를 견고하게 하며, 도깨비들이 출몰하지 못하게 하 고, 인(仁)과 의(義)에서 벗어나는 일에 대해 벌을 내린다.

규벌영관왕천군(紏代靈官王天君)은 남극화뇌적심충량맹리왕원사(南 極火雷赤心忠良猛吏王元帥)라고도 한다. 도경에 의하면, 왕령관(王靈 官)의 본명은 왕선(王善)으로서 송 휘종 때 회음(淮陰) 지역에서 제 사를 드리고 모셨던 작은 신이었다. 후에 살수견진인(薩守堅真人) 이 그의 사당을 불태웠으므로 그는 살수견진인을 미워하여 12 년 동안을 그를 추격하던 중, 계율을 어기고 보복을 행하였으나, 일을 이루지 못하자 다시 성심을 되찾고 살수견(薩守堅)에게 항복하였 다. 이에 옥황대제가 그에게 '선천주장'(先天主將)이라는 칭호를 하 사하고 천계와 인계의 분규(紛紏)를 감찰하게 하였다. 규벌영관왕 천군의 형상은 일반적으로 붉은 얼굴에 수염이 있으며, 금 갑옷에 홍색 도포를 입고, 세 개의 눈으로 노려보며, 왼손에는 풍화륜(風 火輪)을 오른손에는 채찍을 들고 있다. 『도법회원』(道法會元) 242 권에서는 “붉은 얼굴, 붉은 머리칼에 두 눈은 맑게 불타는 듯 하 며, 홍색 도포를 입고, 녹색 신발을 신고 있으며, 풍대(風帶)를 두 르고 있고, 왼손에는 화차(火車)를, 오른손에는 금 채찍을 들고 있 는데, 그 모습이 험악해 보인다.”라 하였다. 충절이 강한 왕원사 (王元帥)는 이후 도교에서 숭앙하는 호법신(護法神)이 되었으며, 거의 모든 도교의 궁관(宮觀)에서 받드는 신이 되었다. 


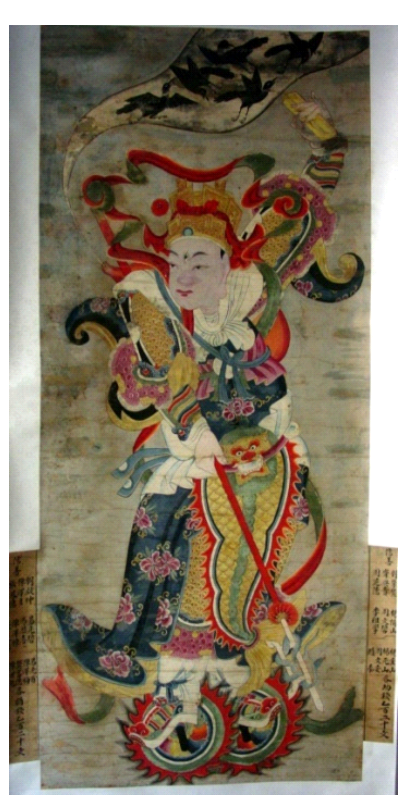

<그림 7> 마원사(馬元帥)상 [청대 회화, 리웬구어 소장]

두신영관마원사(魁神靈官馬元帥)는 영 관마원사(靈官馬元帥), 화광천왕(華光天王), 화광대제(華光大帝), 마천군(馬天君) 등으 로 불리는 도교의 호법천신(護法天神)이 다. 삼교원류수신 대전 (三教源流搜神大全) 제5권에서는 두신영관마원사가 행운과 복의 화신으로서 다섯 겹으로 된 불꽃의 형상으로 마씨금모(馬氏金母)에게 잉태 되었다고 한다. 그의 형상을 보면 세 개 의 눈을 지니고 있으며, 묘악천존(妙樂 天尊)으로부터 천서(天書)를 받아 풍뇌 용사괵귀안민지술(風雷龍蛇酋或鬼安民之 術)을 터득하여 모든 악귀를 물리치는데 정통(精通)하였다. 그는 또한 금으로 된 세 개의 뿔이 있어 무궁한 변화를 행할 수 있다. 옥제(玉帝)의 칙령을 받들어 풍 화지신(風火之神)을 굴복시켜 풍륜(風輪)과 화륜(火輪)을 부리며, 백가성모(百加聖母)를 굴복시켜 화아(火鴉) 오백 마리를 얻었는가 하면, 오룡대왕(烏龍大王)을 항복케 하여 수하로 만들고, 양자강의 용을 참하여 백성들의 안위를 도왔다. 많은 어려움 속에서도 여전 히 충절을 지켰으므로, 옥제는 그에게 좌인우검(左印右劍)을 하사 하고, 남천문(南天門)의 일을 관장하게 하였으며, 처자와 재물에 관한 복을 다스리게 하였다. 백 번 우러러 모시면 백 번을 응하므 로, 무가(巫家)에서는 그를 원한을 풀어 주는 가장 중요한 기도의 대상으로 삼았는데, 기도를 올리면 곧장 천문(天門)에 올라 천제 (天帝)에게 고하여 뇌와 바람을 운용한다고 알려져 있다.

조원사(趙元帥)는 조공명(趙公明)이라 이르며 고상신소옥부대도 독(高上神霄玉府大都督)이라 불려지기도 하는데 도교의 호법대신 (護法大神)에 속한다. 이와 관련하여『도법회원』(道法會元) 232권 
에서는 아래와 같이 말하고 있다. “원사(元帥)의 성은 조(趙)씨로 서, 이름은 랑일(朗一)이고, 일명 창(昶)이라고도 하며, 자(字)는 공 명(公明)으로서 종남산인(終南山人)이다. 진(秦)나라 때 산으로 피 난하였는데, 정심으로 도를 닦아 공(功)과 행(行)이 원만하였으므 로, 옥제가 신소부사(神霄副帥)로 임명하였다. 조원사가 입은 옷의 색깔과 머리에 철관(鐵冠)을 쓴 것 그리고 손에 철 채찍을 든 것 과 얼굴색이 검고 수염이 있는 것은 북기(北氣)에 속함을 뜻한다. 또한 조원사가 호랑이를 타고 있는 것은 서쪽의 금기를 지녔음을 뜻하는데, 그는 천문(天門)의 명을 받들어 삼계(三界)의 일을 계획 하며 오방(五方)을 순찰(巡察)하고 구주(九州)의 일을 책임지는 직 전대장군북극시어사(直殿大將軍北極侍御史)이기도 하다. 조천사(祖 天師) 장도릉(張道陵)이 대단(大丹)을 수련할 시에 옥제에게 용맹 한 신리(神史)의 수호를 받을 수 있기를 청하였는데, 이로써 조원 사가 옥제의 명을 받들어 정일현단원사(正一玄壇元帥)의 소임을 맡게 되었다. 조원사의 부하로서는 팔왕맹장(八王猛將)이 있는데, 이들은 팔개(八卦)에 응한다. 또한 육독대신(六毒大神)이 있는데 이들은 천살(天憊), 지살(地棂), 연살(年棂), 월살(月㙰), 일살(日㙰), 시살(時憊)에 응하며 오방뇌신(五方雷神)과 오방창병(五方猖兵)은 오 행(五行)에 응한다. 이 외에도 이십팔장은 이십팔수에 응하며 천(天) 과 지(地)가 합한 이장(二將)은 천문지호(天門地戶)의 열고 닫음을 책임진다. 이 외에도 수화이영(水火二營) 장군은 춘생추살(春生秋 棂)의 소임을 맡았다 한다. 조원사는 뇌(雷)와 번개를 부리며, 바 람과 비를 부르고, 전염병을 물리치고 재난을 막으며, 병을 다스리 고 액을 물리치니 그 공이 실로 크다 하겠다. 조원사는 또한 억울 한 소송에 대한 원을 풀어 주며, 공평한 매매, 재물을 구함과 화합 에 이로우며, 지극히 공정한 바를 구하여 기도하면 여의하지 않는 일이 없다. 조원사의 형상을 말하자면 얼굴빛은 철색(鐵色)을 띠 며, 둥근 눈에 검은 수염이 있고, 철 투구를 쓰고 있으며, 이마에 
는 황색 비단을 두르고 있고, 검은 도포와 금 갑옷을 입었으며, 녹 색 신발을 신고, 오른손에는 이십사절철편(二十四節鐵鞭)을 들고, 왼손에는 철삭(鐵索)을 들고 있는데, 검은 호랑이가 그를 따르고 있다.37)

온경원사(溫瓊元帥)는 '온태보'(蘊太保)라고도 한다. 전하는 바에 의하면 온경원사는 절동온주평양현(浙東溫州本陽縣) 사람으로 자 (字)는 자옥(子玉)이다. 그의 어머니가 '남방일륜'(南方日輪)의 꿈을 꾸고 그를 잉태하였으므로 태보(太保)라 이름하였다. 자라서는 뜻 을 세우고, 무(武)에 능하고 용감하여 당나라 때의 곽자의(郭子儀) 를 따라 출전하여 도적떼를 평정하였으며, 선봉에 서서 진두지휘 하였으므로 전장에서 많은 상처를 입었으나 굴하지 않았다. 후에 태산으로 들어가 동악묘(東获廟)에서 3년을 정진하여 악부태보(嶽 府太保)로 화(化)하였는데, “악제(获帝)의 명으로 지부명사(地府冥 司)에서 급히 사람을 구해내야 하는 일을 맡게 되었으므로 사람의 생사를 관장하게 되었다.”38) 이외에도 온경원사는 엽법선(葉法善) 을 도와 마(魔)를 굴복시켰으므로 그 명성이 서촉까지 알려지게 되었다. 양송(兩宋) 시기에 오사경(吳思敬), 장허정(張虛靖), 왕종경 (王宗敬), 오도현(吳道顯), 유백기(柳伯期) 등의 도가 높은 도사들 이 ‘지지온태보법비법’(地祇溫太保秘法)을 세상에 전할 것을 제창 하게 되었고 이에 온태보(溫太保)의 신앙은 남방의 각지에 널리 전해지게 되었다. 온경원사의 형상은 위엄이 있고 용맹스러우며, 신장은 구 척 이상에 이르고, 얼굴과 손은 푸르다. 또한 그는 송곳 니에 입술, 머리, 눈썹이 모두 붉으며 금색 눈에 흉악스러운 모습 이다. 또한 자색의 수건으로 머리를 감싼 채 매와 꽃이 그려진 푸 른 도포(鷹花綠袍)를 입고, 허리에 금띠를 두르고 있으며, 검은 장 화를 신고, 표범 가죽의 지팡이를 들고 있다. 또한 손에는 금골타

37）『道藏』, 第30冊, p.446.

38）黃公瑾，『地祇上將溫太保傳』，『道藏』, 第 18 冊, p.91. 
(金骨朵)를 들고 있는데 때로 마를 항복시켰다는 의미로 장리검(仗 利劍)을 들고 있기도 하다. ${ }^{39)}$

낭령상장관원사(朗靈上將關元帥)는 관우(關犲)라고도 하는데 탕 마진군(蕩魔真君), 복마대제(伏魔大帝), 관성제군(關聖帝君), 풍도랑 령괵마관원사(剚都朗靈䊀魔關元帥), 삼계복마 대제신위원진천존관성 제군(三界伏魔大帝神威遠震天尊關聖帝君)이라고도 불리며 ‘관제’라 간칭하기도 하고 속칭 '관공', '관나리’라 불리기도 한다. 관제신앙 은 삼국시대 촉나라의 명장 관우에서 그 유래를 찾을 수 있다. 관 우는 오나라와의 접전 끝에 죽었으므로 그의 시호를 장무후(壯紾 (侯)라 하였으며, 사당을 지어 그 공적을 기렸다. 북송의 휘종 시기 에 장허정(張虛嗉) 천사의 간청으로 해지(澥池)의 교룡을 없애고 왕에게 현신하였으므로 왕이 그를 '숭녕지도진군'(崇寧至道真君)에 봉하였다. 명·청 이래로 관제신앙은 교문(教門)에 국한되지 않았으 며, 국가의 제전에 포함되게 되었다. 또한 관제는 민간에서도 숭배 하는 신이 되었다. 관성제군은 무신(武神)이면서도 재신(財神)이며, 또한 사명록(司命祿)을 지니고 있고, 과거(科舉)를 좌우하고, 병과 재해를 물리치며, 사귀를 쫓고, 반역자를 벌하며, 명사(冥司)를 순 찰하고, 상가(商賈)를 보호하고, 보화를 들어오게 하는 기능신으로 서 그의 법력은 실로 무한하다고 할 수 있다. 관제신앙이 이렿듯 널리 알려짐으로써 수를 헤아릴 수 없을 만큼의 관제묘(關帝廟)가 세워지게 되었고 그 신앙이 널리 퍼지게 되었다. 도경(道經)에서는 관제의 형상에 대해 다음과 같이 말하고 있다. "원사(元帥)는 짙은 대추 색의 얼굴에 봉황의 눈을 하고 있으며, 삼각수의 길이가 1 척 8촌에 달한다. 또한 천청결건(天青結巾)을 쓰고, 붉은 조복을 입 고, 옥대를 차고 있으며, 검은 장화를 신고 용두대도를 들고 있는 데, 적토마가 그를 따르고 있다. 기쁜 얼굴을 한 모습은 괵섭(戎 攝)과 유사하며, 노한 얼굴은 뇌문에 이르렀음을 의미한다.”40)

39）『道法會元』, 卷二五四, 『道藏』, 第30冊, p.560. 
뇌정십사(雷霆十帥)를 중심으로 방(龐), 도(陶), 유(劉), 진(秦), 조 (趙) 등의 천군(天君) 및 섬뇌신(閃電神), 조풍신(助風神) 등 구름과 비를 재촉하는 이십사원(二十四員)의 호법천군(護法天君)이 있는데 이들을 뇌부(雷部)의 이십사천군(二十四天君)이라 이른다. 『봉신연 의』(封神演義)에서는 은(殷)나라 때의 재상이었던 문중(聞仲)이 구 천응원뇌성보화천존으로 화(化)하였다고 이른다. 그는 뇌부이십사 원(雷部二十四員)을 통솔하며 운우(雲雨)를 재촉하는 호법천군(護 法天君)으로서 구름과 비를 부려 만물이 생장하게 하고, 반역자와 간악한 자를 멸하고, 선악을 행하는 바에 따라 화 혹은 복을 내린 다. 뇌성보화천존은 검은 기린을 타고 음양의 채찍을 사용하는데 그 채찍은 두 마리의 교룡(蛟龍)으로 이루어져 있다. 그 수하인 뇌 부천군정신(雷部天君正神)의 휘(諱)로는 등천군충(鄧天君忠), 신천 군환(辛天君環), 장천군절(張天君節), 도천군영(陶天君榮), 방천군홍 (龐天君洪)，유천군보(劉天君甫)，구천군장(苟天君章), 필천군환(畢 天君環), 진천군완(秦天君完), 조천군강(趙天君江), 동천군전(董天君 全), 원천군각(袁天君角), 이천군덕(李天君德), 손천군량(孫天君良), 백천군예(柏天君禮), 왕천군변(王天君變), 요천군빈(姚天君賓), 장천 군소(張天君紹), 황천군경(黃天君庚), 금천군소(金天君素), 길천군립 (吉天君立), 여천군경(余天君慶), 섬뇌신(閃電神), 조풍신(助風神), 함지선(菡芝仙)이 있다.

남송(南宋) 이래 뇌성보화천존 신앙이 매우 성행하여, 『옥추보경 』이 광범위하게 발간되었다. 가정(嘉定) 12년 (1219)년 정월 5일 에 백옥섬(白玉蜳)이 양백자(楊伯子)를 파견하여 팽려(彭耜)에게 서한을 보내 천계에서 정식으로 신직(神職)이 주어졌음을 알렸으 며, 그로 하여금 뇌경(雷經)을 세상에 전하게 하였다.

중국의 민간에서는 뇌성보화천존의 신앙이 매우 보편적이다. 『역 대신선보감』(歷代神仙通鑒) 제 4 권에서는 황제가 득도하여 승천한

40) 같은 책, 卷二五九, 『道藏』, 第30冊, p.588. 
후에 구천응원뇌성보화진왕(九天應元雷聲普化真王)에 봉해져 뇌성 에 거하며, 진왕(真王)의 앞에 36면(面)의 뇌고(雷鼓)가 자리하고 있고, 36신(神)이 이를 지키고 있다고 말한다. 뇌(雷)를 행할 시에 는 진왕(真王)이 직접 본부의 뇌고를 울리며 이에 뇌공(雷公)과 뇌 사(雷師)가 즉시 뇌성을 울린다. 『봉신연의』에서는 뇌부(雷部)의 정 신(正神)이 문중이며, 그가 뇌부의 이십사호법천군(二十四護法天君) 을 통솔한다고 말한다. 이 외에도 『서유기』에서는 손오공의 청에 응해 뇌성보화천존이 등(鄧), 신(辛), 장(張), 도(陶) 등 모든 사(師) 로 하여금 뇌부의 신장들을 이끌게 하여, 대성인(大聖人)을 따라 하계에 법을 전하게 하였다고 말한다. 이러한 문예소설의 영향으로 민중들은 뇌성보화천존을 더욱 널리 숭배하게 되었다.

\section{III. 보화천존신앙(普化天尊信仰)의 과의(科儀)방법}

민중의 종교 신앙은 각종 의식과 방법을 필요로 하는데 이로써 종교적 예를 나타낸다. 사람들이 신성한 전당에서 향을 피우고 기 도하며 머리를 조아리고 절을 하면 인신(人神)간에 감응이 있게 된다. 또한 법사가 우보(禹步)를 행하고, 손으로는 인결(印訣)을 행 하며, 주문을 외우고, 액을 물리치고 복을 부르는 법회(法會)를 거 행하면 사람들은 전자에 비해 신령이 주는 복을 더욱 많이 받게 된다고 알려져 있다. 각양각색의 과의와 공법은 여러 가지 상황에 상응하여 생겨나게 되며, 또한 시대적 배경에 의해 변천하게 되는 데, 아래에서는 뇌정(雷霆)의 과의(科儀) 방법에 대해 설명하고자 한다.

뇌정사과(雷霆謝過)에 관한 초의(醮儀)는 기복사과(祈福謝過)의 과의에 속한다. 이는 '사과'(謝過)라고도 하는데, 이는 자신의 잘못 
을 인정하고 뉘우쳐 신령에게 머리를 조아리고 절을 올리며 죄송 함을 표하는 것이다. 『명진과』(明真科)에서는 “마음으로 믿는 자에 게 응하게 되며, 향을 피우고 원하는 바를 빌면서 절을 올리면 신 이 이를 꿰뚫어 보게 되므로 전생(前生)의 죄업이나 사후(死後) 공 과(功過)를 셈하는 문제가 해결된다.”, “허리를 굽혀 절을 하고 머 리를 조아려 삼가 하면 자연히 '마음으로 정성을 다하는'(意盡精 誠) 경지와, '자연의 도를 깨닫는'(自然感徹) 경지에 도달하게 된 다. 도교에서는 인생에 많은 과실이 있어 이로 인해 갖은 재화(災 禍)가 발생 한다.”고 말한다. 그러므로 도교에서는 자신이 죄 지은 바와 잘못을 빌고, 해원(解冤)의 방식으로 맺힘을 푸는 법문(法門) 으로 보화천존께 빌 것을 권한다.

재초(齋醮)는 도교에서 행하는 전통적 의식을 이르는 말이며 속 칭 '도장'(道場)이라고도 한다. 이는 또한 수도하여 도를 행하는 중 요한 내용이다. 도교에서 재초(齋醮) 의례와 범절을 행하는 목적에 는 두 가지가 있는데, 그 중 한 가지는 수도(修道)이며, 또 다른 하 나는 신(神)과 통하는 것이다. 도교의 재초의식(齋醮儀式)은 복잡한 구조를 지니고 있다. 재초의식은 다양한 독립적인 과의로 구성되어 있으며, 각각의 과의 또한 특정한 신학적 의의와 작용을 구비하고 있다. 예를 들면 선천두식제련유과(先天斛食濟煉幽科)는 공통적으 로 망자를 구원하는 의미를 지닌 '연도'(煉度), '제유'(濟幽), '두식' (斛食)의 삼의(三儀)로 구성된 대형의식인데, 매번 이를 행할 때 마 다 4시간의 시간을 요한다. 과의를 행할 때 도사가 신기(神氣)로 변해 두 가지의 상(象)에 응하는 진(津)이 되어 망령(亡靈)의 신체 로 들어가 망령이 제도되도록 한다. 매 과의는 또한 독립적인 뜻을 지닌 의식으로 구성되어 있는다. 예를 들면, 도사가 제단에 오름을 뜻하는 승단(升壇), 향로에 향을 피우는 의미인 발로(發爐), 도사가 자신이 속한 도파를 신에게 고하는 서직(署職), 기도와 주문을 염 송하는 창방(唱方) 등이 이에 속한다. 많은 과의가 함께 조합되어 규모 있는 의식이 되는데 이것이 곧 제초법회(齋醮法會)이다. 예를 
들면 의식의 과정에 구천의 구황금록대재(九皇金籙大齋), 삼천(三 天)의 하원황록대재(下元黃筡大齋)를 거쳐야 한다. 모든 독립된 과 의가 조합되어 모시(某時) 모처(某處)에서 거행되는 대형 재초 법 회의 신학(神學)적 요구에 부합되게 되는 것이다.

뇌정사과(雷霆謝過)에서는 초의(醮儀)가 준 비되는데, 이는 신소파 법사가 주관하는 제 초법회(齋醮法會)이다. 법회에서 법사는 탑강 보허(踏罡步虛)를 행하며, 초단(醮壇)에서는 염송과 보행을 함께 행한다. 또한 궁관을 돌 고 무릎을 꼻고 땅에 머리를 조아려 절하며, 꽃을 뿌리고 향을 피우며, 동장(洞章)을 을조 리고 몸을 앞으로 향하게 하고 눈으로 내면 을 바라보며, 천존의 자리에 앉아 현진(玄真) 을 부르며, 그 마음과 형상이 현진과 동일해 지도록 한다. 삼헌법사(三獻法事)를 행한 후 법사는 삼청상성(三清上聖), 십극고진(十極高 真), 만천상제(萬天上帝), 일월성수(日月星宿), 성부조료(省府曹僚), 지수옥독성융사령(地水嶽 瀆城隆社令)과 초제 내외의 일체진령(真靈) 법

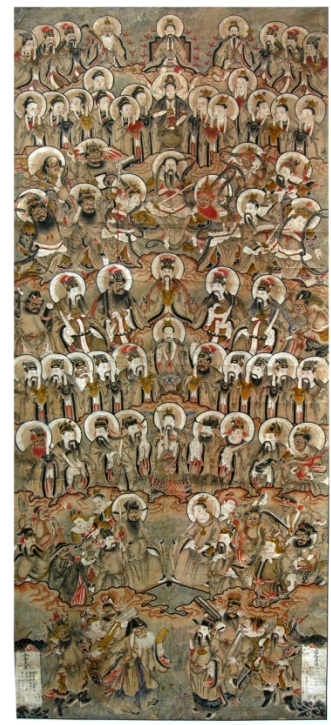

〈그림 8> 도정종사도(道正宗師圖) [청대 회화, 리웬구어 소장] 위에 대해 정성을 드리며 그 은덕에 감사한다. 그런 연후에 찬사 (贊詞)를 선포하고, 초관(醮官)과 함께 머리를 조아리고, 제단의 제 물을 뿌려 신에게 바친다. 법회 중에는 '신을 청하는 의식'(請聖)을 행하는데, 법사(法師)와 법단(壇官)의 관중들은 경건하게 천지제신 (天地諸神)이 강림하기를 청한다. '신의 강림'(降聖) 의식을 행하면 학이 이끄는 수레가 당도하고 삼계의 신장이 모두 이르므로 의법 에 따라 예를 행한다. 의식을 행한 준비가 모두 완비되었을 때 법 사가 제단 앞에 이른다. 초관(醮官)은 향을 피우고 절하며 술을 올 리도록 한다. 사람들이 표문(表文)을 올리면, 도사는 신중들의 기 원이 담긴 표문(表文)을 천정(天庭)에 보내고 상제에게 고한다. 신 
이 성스러운 빛(聖光)으로 초단(醮壇)에 강림하면 복과 수명을 내 리며 선령들이 구제되도록 한다. 서로 다른 목적에 의해 행해지는 의식에 따라 상제에게 고하는 표문의 내용이 달라진다. 천궁(天宮) 에 전해지는 표문(表文)은 제단에서 법사(法師)가 선독(宣讀)한 후 다시 분표장(焚表場)에서 불태운다. 제단을 둘러싼 법중(法眾)은 경을 낭송하고 경을 송독하는 것으로써 수도를 행하는데 도움이 되도록 한다. 백옥섬은 송경(誦經)에 대해 “천존을 대신하여 연설 을 하고, 경(經)으로 가르침을 주며, 대도(大道)로써 중생을 계도하 는 것이다”고 하였는데, 여기에는 전교(傳教)와 법을 널리 전파하 는 의미를 포함한다.

구천응원뇌성보화천존옥추보참(九天應元雷聲普化天尊玉樞寶懺) 은 도사가 죄를 뉘우치고 복을 비는 신도들을 위해 행하는 참의 (懺儀)이자 참회문식(懺悔文式)이다. 이를 행함에 있어 먼저 도사 가 신도들을 이끌고 신께 예를 올리며 '구천응원뇌성보화천존'의 신위(神威)와 공덕(功德)을 찬양한다. 다음으로 자신의 죄업을 참 회하고, 자신의 마음을 삼보(三寶) 및 모든 천존신령(諸天尊神靈) 에게 귀명(歸命)하도록 하며, 죄를 사하고 복을 내려 줄 것을 빈 다. 법사가 이렇게 의식을 행한 후 순서에 따라 염송하며 삼청(三 清)에 예를 갖추어 귀명하고 도보(道寶), 경보(經寶), 사보(師寶)에 귀의하며 중생들이 법교(法橋)에 올라 제도되는데 있어 장애가 없 도록 한다. 도장(道場)에 모인 사람들은 마음으로 예참(禮懺)의 법 례를 올리고, 경건한 마음으로 공손하게 조례(朝禮)하며, 구천응원 뇌성보화천존에게 귀의한다. 한 번 절을 올린 후 구천응원뇌성보 화천존에게 귀의하는 마음으로 다시 성호를 아홉 번 부르고 아홉 번 절을 올린다. 이에 법사는 다시 허보(虛步)를 행하며 경을 읖조 리는데 참가자들은 진심으로 귀의한 마음으로 남극장생대제통천원 성천존(南極長生大帝統天元聖天尊), 동극청화대제태일구고천존(東極 青華大帝太一救苦天尊), 구천가한장인주릉도명천존(九天可韓丈人朱 陵度命天尊), 구천뇌조대제제재제물천존(九天雷祖大帝除災濟物天尊), 
벽옥궁태일 대천제보제겁운천존(碧玉宮太一大天帝保制劫運天尊), 육천 동연 대제복마상상태을천존(六天洞淵大帝伏魔上上太乙天尊), 육파천주 제군보시법윤천존(六波天主帝君普施法潤天尊), 구천탐방사진군응원 보련묘화천존(九天採訪使真君應元保運妙化天尊), 구천응원부경사사 상일체선진(九天應元府卿師使相一切仙真), 뇌부진선제사관속(雷部真 仙諸司官屬)을 향해 무릎을 꼻고 절을 올리고 참회한다.41)

구천벽담뇌도우대법(九天碧潭雷檮雨大法)은 부려원시천존(浮黎元始 天尊), 호천옥황상제(昊天玉皇上帝), 후토황지지(後土皇地祇), 구천뇌 조대제(九天雷祖大帝), 구천응원뇌성보화천존(九天應元雷聲普化天尊) 을 위주로 하는 뇌법인데, 이러한 신들에게는 많은 수하 뇌신들이 있다. 또한 이러한 뇌공(雷公)들은 그 형상이 매우 특이한데 머리 에 뿔이 나 있고, 매의 부리를 하고 있으며, 금색의 눈동자에 겨드 랑이 양 쪽으로 날개가 자라 있고, 용의 발톱을 지녔으며, 도포를 입고 허리띠를 매고 있다. 기우(新雨)의 대상이 되는 뇌공은 얼굴 이 검은데, 법사는 물을 뿜어내는 방식으로 의식을 행한다. 기청 (祈晴)의 대상이 되는 뇌공은 얼굴과 몸이 붉은데, 법사는 불을 뿜 어내는 방식으로 의식을 행한다. 또한 기설(新雪)의 대상이 되는 놔공의 얼굴과 몸은 흰데, 이 때 법사는 눈을 뿌리는 방식으로 의 식을 행한다. 법사는 뇌를 부리고 운용하는데 먼저 가부좌를 한 상태에서 행공(行功)해야 하며 내련으로 일을 행하되 시간에 맞춰 공을 드림으로써 천지의 기를 받도록 한다.

상술한 내용은 도교법사가 행하는 방식으로서 보통의 민중이나 신도들은 간단하고 익히기 쉬우며, 진행하기 간편한 수양법을 선택 해야 할 것이다. 민중이나 신도들이 행하기에 적합한 방식으로서 천민소두법(天民梳頭法), 천민출입법(天民出入法), 천민제죽법(天 民齋䉼法), 천민목욕관대법(天民沐浴冠帶法), 천민해의법(天民解衣 法), 천민임와법(天民臨臥法), 천민우질복약법(天民遇疾服藥法), 천 민리예입암법(天民履穢入暗法), 양악몽법(禳惡夢法), 안오장법(安五

41）『九天應元雷聲普化天尊玉樞寶懺』, 『道藏』, 第3冊, pp.549-550. 
藏法), 안이명법(安耳鳴法), 거재액법(去災厄法), 환신법(還神法), 명 목법(明目法), 자해우수법(自解憂愁法) 등이 있는데 이는 모두 일 반인들이 간편하게 행할 수 있는 편리한 '법문’(法門)이다.

일반인들이 행하기 쉬운 간편한 법문은 널리 유전되었는데, 그 중에서도 법문을 염송하는 방법이 가장 중요하다 하겠다. 즉 도를 행하는 이가 늘 경건한 마음으로 천존의 성호를 오랫동안 염송하 게 되면 완전한 공덕을 이루는 경지에 도달할 수 있다. 『옥추보경 』은 보화천존의 법문(法門)으로서 세인들이 어리석음을 벗게 해 주 고, 세속의 탁함을 맑게 하여 주며 많은 사람들을 도로써 구제하여 준다. 일상생활 속에서 성심으로 보경을 염송하고 구천응원뇌성보 화천존의 보화를 부르면, 혼령이 편안함을 얻고 심맥(心脈)이 안정 을 얻게 된다. 형(刑)을 당할 위험이 있는 경우에는 경을 염송하여 흉살을 면하도록 하는데 “『옥추보경』에 귀명하여 주문을 염송하고 향을 피우며 부(符)로써 고하게 되면 일체의 액난을 제거할 수 있 다.” 이 외에도 오랜 질병으로 고생하고 있을 때, 혹은 결혼 후 분 만이 어려울 때, 귀신과 요괴들의 괴롭힘에 시달릴 때, 경을 염송 하고 부를 태우면 몸이 편안해지고 길함을 얻게 된다. 이렇게 볼 때『옥추보경』은 불가사의한 공덕을 지니고 있는데, 이에 대해『 옥추보경』에서는 “천존의 힘을 얻어 영통함을 얻게 된다. 출입하 고 기거하는 데 있어 언제나 본경을 지니고 있으면 많은 사람들의 존경을 얻을 것이며 귀신이 두려워할 것인 바, 난관에 봉착했을 때 일심으로 구천응원뇌성보화천존을 부르면 모든 어려움이 해소 되고 해탈을 얻을 것이다.”42)라 이르고 있다.

이러한 염송법은 '십자천경법'(十字天經法)이라고도 하는데, 여기 서 열 개의 글자라는 의미는 기실 뇌조(雷祖)의 성호(聖號)를 가리 키는 것이다.『옥추보경』에 의하면, 십자천경(十字天經)은 다음의 십대효력을 지니고 있다.

42)『道藏』, 第1冊, pp.759-760. 


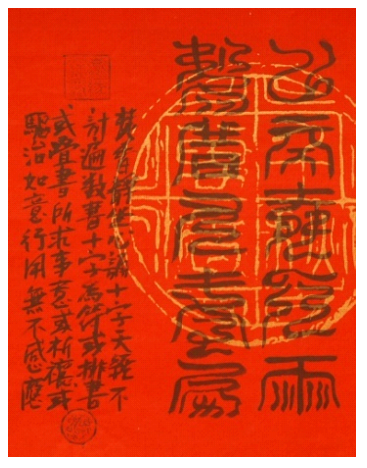

<그림 9>

십자천경부(十字天經符)

[리웬구어 그림]
(1) 심맥이 편안해지고, 사람이 안정을 얻으며, 심신이 건강해져서 연년익수(延 年益壽)를 누리게 된다.

(2) 고난에서 벗어나며, 재액이 소멸되 고, 구설에 휘말리지 않으며, 영원히 송 사를 면한다.

(3) 질병이 해소되고, 전염병이 물러가 며, 모든 질병의 고통이 사라진다.

(4) 부부가 화목하고, 태아를 보호하 며, 영아를 지켜 주고, 자손이 끓이지 않 게 한다.

(5) 사악한 귀신을 몰아내고, 도깨비와 요괴를 굴복시켜, 혼백이 편안하도록 하 고, 심신이 안정되게 한다.

(6) 망혼을 구제하고, 칠조구선(七祖九先)이 음계를 벗어나 새로운 생을 얻도록 한다.

(7) 물길과 육로를 출입하는데 어려움이 없이 편안토록 하 며, 재물과 길한 운이 따르도록 하며, 사해(四海)에 복이 가 득하게 한다.

(8) 바람과 비를 조화롭게 하며, 사계가 평안하고 오곡이 풍성하며, 복록이 가득하고 안녕 되게 한다.

(9) 더러움을 벗어나게 하고, 도와 합일을 이루게 하여 덕 을 쌓고 정진하는데 마가 방해하지 않게 하며, 반드시 득도 하도록 한다.

(10) 악업을 물리치고 선으로써 일을 성취케 하며, 천존을 배알하여 공덕을 증험케 한다.

무릇 진심으로 도를 구하는 자나, 혹은 마음으로 도에 정진코자 하나 명사를 만나지 못한 자, 혹은 병으로 시름하며 혼백이 불안 하거나 운명이 평탄하지 않고 오랜 동안 어려움을 겪거나 관부의 구설에 휘말리거나 신살(神薢)이 있어 잘못을 저지르거나 결혼하 여 자식을 얻고자 하거나 집안에 잡귀가 있거나 악한 저주에 시달 리거나 돌림병이나 독충의 해를 입거나 길을 떠나거나 은둔하고자 하거나 비 오기를 청하거나 삼재구횡(三災九橫)을 면하고자 하거 나 죄업을 참회하고자 할 때, 『옥추보경』을 외우고 진심으로 십자 
천경을 염송하면 스스로 감응을 얻을 것이며 재해를 물리침을 알 게 된다는 것이 보화천존의 법문인 것이다.

보화천존은 이렇듯 간편한 법문으로 제세도인(濟世度人)하는데 그 성호를 염송하게 되면 질역(疾疫: 병마로 고생함), 도병(刀兵: 전쟁), 구유(九幽: 지옥), 형살(刑殺: 형벌이나 살겁), 극해(克害: 상 극으로 해를 입음), 탐요(貪夭: 탐욕으로 요절함), 상잔(傷残: 상처 를 입어 몸이 여의치 않음), 고과(孤棎: 고독함), 화해(禍害: 재난 으로 해를 입음), 겁살(劫繁: 겁액의 살), 재살(災繁: 재액의 살), 세살(歲繁: 나이의 살), 파패(破敗: 실패함), 원왕(冤枉: 억울함), 관 재(官災: 관직으로 인한 재액), 뇌옥(牢獄: 감옥에 가게 됨), 천액 (天厄: 하늘의 액), 지액(地厄: 땅의 액), 수액(水厄: 물의 액), 오방 액(五方厄: 오방의 액), 사시액(四時厄: 사시의 액), 본명액(本命厄: 본명의 액), 천온(天瘟: 하늘의 역병), 지온(地瘟: 땅의 역병), 천고 (天䓝: 하늘의 독충에 의한 해), 지고(地蜔: 땅의 독충에 의한 해), 천채(天瘵: 폐병의 일종), 지채(地瘵: 폐병의 일종), 복연(複連: 손 발이 무겁고 여위는 병), 복시(伏屍: 전염병), 고기(故氣: 사악한 기운), 귀주(鬼注: 신병), 천재(天災), 화재(火災), 수재(水災) 등의 재액을 면할 수 있다고 믿어졌다. 『옥추보경』을 염송하거나 구천 응원뇌성보화천존의 성호를 부르면 많은 사람이 해탈할 수 있게 되며, 심맥을 편안케 하고, 액난과 질병을 물리치며, 결혼이 성사 되고 태아가 보호되며, 사악한 귀신이 물러가고, 망혼을 구원하며, 구설에서 벗어나고, 영원히 송사에 휘말리지 않으며, 사람과 물상 이 모두 편안하고, 물길과 육로가 평강하며, 풍우가 순조롭고 재액 이 소멸되는 불가사의한 증험을 지니고 있으며 이 뿐만 아니라, 진실로 깨끗한 경지에 도달토록 한다고 믿어졌기에『옥추보경』은 민중의 세계에 깊은 영향을 끼쳤으며 광범위하게 알려져 그 주해 나 주석본 만도 20 여 종이 될 정도로 송 - 원 이래의 핵심적인 도 교 문헌의 하나로 자리매김하였다. 


\section{$\mathrm{IV}$. 한국의 보화천존신앙}

『옥추보경』은 세상에 알려진 후로, 일본과 한국 등지로 급속히 전파되었다. 한국의 안동준(安東浚) 박사는 『論韓國醫學與道教之關 係』라는 글에서 역사상 고려 왕조와 북송 휘종 시기의 교류에 대 해 논술한 바 있는데, 고려회(高麗勫)에서 청우(靑牛)를 휘종에게 선물하자 휘종이 그 답례로 『옥추보경』을 전했다는 논지로서, 고 려시대에 이미 신소뇌법(神霄雷法)이 전해졌다고 말하고 있다. 고 려 예종(睿宗) 13년(1118년) 7월에 송 휘종이 양종립(楊宗立), 병 의랑(秉義郎), 조의(曹誼), 두순거(杜舜舉), 성상적(成湘迪), 진종인 (陳宗仁), 남줄(藍茁)의 일곱 의사를 고려에 파견 출사토록 하여 2 년간 의학을 전수하게 하였는데 이로써 중국 도교의학이 고려에 전승되었음을 알 수 있다. 당시 고려에 전해졌던 도교의학은 곧 신소파의『옥추경』을 위주로 한 치료법이었다. 정화(政和) 연간에 송과의 교류를 통해 고려의 도교는 복원궁(福源宮)을 중심으로 발 전되었으며 중국 도교의 영향을 받아 옥황상제(玉皇上帝), 태상노 군(太上老君), 뇌성보화천존을 숭배하였다. 조선 초기에 도관을 관 장했던 국가 기관인 소격서(昭格署)에서 도사를 선발할 때에는 필 히『금단』(禁壇), 『영보경』(靈寶經), 『연생경』(延生經), 『태일경』(太 一經) 『옥추경』(玉樞經) 『진무경』(眞武經)、『용왕경』(龍王經)을 염 송하였다. 또한 입춘, 입하, 입추, 입동, 춘분, 추분, 동지, 하지의 8절 초제를 행할 시에『옥추경』을 을었다.43)

명 - 청시대에 뇌성보화천존 신앙은 일본과 한국 등에서 매우 보 편화 되었다. 허준(許浚)이 주편(主編)한 『동의보감』(東醫寶鑒)을 보면, 도교가 한국 의학에 중대한 영향을 끼쳤음을 알 수 있다. 동 의보감은「내경편」(內景篇),「외형편」(外形篇),「잡병편」(雜病篇),「 탕액편」(湯液篇),「침구편」(針炎篇)으로 구성되어 있는데, 동의보감

43）安東浚, 「論韓國醫學與道教之關係」, 『道學研究』5（2005). 
의 특징은 곧 도교의 교리를 의학의 본질로 하고 있다는 것이다. 내경편」은 도교의 정기신설(精氣神說)을 운용하면서 병에 앞서 양 생의 의의를 강조하고 있으며「잡병편」은 돌림병과 악령, 독충의 독 등에 대해 언급하면서 실질적인 병의 원인과 치료방법을 제시 하기에 힘쓰고 있다. 그러나 『동의보감』이 이러한 실질적 특징을 지니고 있음에도 고려시대 부록과 주문의 도교 흔적이 완전히 사 라지지 않았음은 물론, 도교적 요소가 때로 현실적인 필요에 의해 활용되었음을 알 수 있는데, 가장 대표적인 예가 곧 '최생부'(催生 符)와 '옥추단'(玉樞丹)이다. 최생부는 출산과 관련이 있으며, 옥추 단은 악령이 몸에 들거나, 상대의 저주에 의한 병(巫蠱)을 치료하 는 데 쓰였다. 옥추단은 비록 신비적 색채를 지니고 있으나 현대적 입장에서 이를 고려해 볼 때 정신요법의 일종이라 할 수 있겠다. 허준이『동의보감』을 완성한 이후, 의료적 영역에서 무의(巫醫)에 이르기까지 돌림병에 관한 치료법이 확대 되었는데, 허준은 말년에 『신찬벽온방』(新纂辟盒方), 『벽역신방』(辟疫神方), 『언해두창집요』(彥 解痘瘡集要) 등을 저술하였다. 이러한 허준의 지속적인 의학적 성 취와 끊임없는 노력은 한국의 의학사에서 길이 빛날 만한 공적이 다. 그러나 그 배경에는 도교의 부주치병술(符咒治病術)을 개혁하 고자 했던 조선 내단학의 영향을 받은 유의(儒醫)들의 도교양생사 상이 자리 잡고 있었음을 결코 배제할 수는 없을 것이다. ${ }^{44)}$

사실『옥추보경』은 조선 사회에서 광범위하게 전파되었다. 민간 에서는 많은 사람들이 옥추경주(玉樞經咒)를 송독하였고, 부록(符 籙)을 운용하였으며, 이로써 병을 몰아내고 잡귀를 물리쳐 태아를 지키고 생명을 지키기를 바랐다. 『한국책판목록총람』(韓國冊板目錄 總覽)의 기록을 통해 보면, 능주(綾州), 동복(同福), 영변(寧辺)의 지 역에서 세 종류의 『옥추보경』 각본이 전해졌다. 그 중 융경(隆慶) 사사경오 (四禩庚午) (1570)에 간행된 동복판(同福版)은 '전라도동 복지무등산안심사개판’ (全羅道同福地無等山安心寺開版)을 근거로

44) 같은 글. 
하였다. 또한 영조(英祖) 9년(1733)에 영변판(甯辺版)이 간행되었 고, 이는 '묘향산보현사'(妙香山普賢寺)라는 불교 사원에서 간인되었 다. 조선에서 각본된 『옥추보경』 제 1 권에서 뇌성보화천존 등을 포 함한 47인의 신상도(神像圖)와 백옥섬(白玉蟾), 장진군(張真君), 장 천군(張天君), 여순양(呂純陽) 등 네 명의 주석이 수록되어 있다.45)

이능화는 『조선도교사』 22장「도교와 맹인」에서 다음과 같이 말하고 있다."도가에는 술수(術數)와 점험(占驗)의 한 파가 있다. 조선의 맹인은 점으로써 업을 삼는 것이 있으니 이것이 바로 이런 파에 속하는 것이다.”, “경을 읽고 잡귀를 쫓는 것이 맹인의 하는 일이다. 이때 맹인이 읽는 경은 불가서(千手經 또는 八陽經 등)나 도가의 경이다. 그러나 천수경이나 팔양경은 간간히 외우기도 하 나 전적으로 외우지는 않고 전문적으로 읽는 경은 옥추경 뿐이 다.” 또한 도사인 맹인이 독경하려 하면 괴황지(槐黃紙) 조각에 주 사를 갈아 구천응원뇌성보화천존부터 소차백마대장군(素車白馬大 將軍)까지 총 48신장의 이름을 써서 병자가 누워 있는 방안에 붙 여놓고, 여러 맹인들이 둘러앉아 북을 치고 독경하기를 혹 사흘, 혹 이레 동안 하여 신장이 강림하여 사귀(邪鬼)를 지하에 묻어버 리기를 청한다고 하였다. 이 내용을 볼 때, 도사(道流僧)인 맹인들 의 이러한 주술은 도교 부록파 주술과 전혀 차이가 없으며, 『옥추 보경』의 도법을 직접적으로 받아들인 것이라 볼 수 있다. 이 외에 도 24장「연중행사와 도교의 관계」에서는 다음과 같이 기록하고 있다. “지금도 우리 민간 풍속에 직성길흉(直星吉冈)에 따라 도액 (度厄)하는 법으로 정월 14 일에 이를 행한다. 이것이 비록 연중행 사의 하나로 되어있으나 그 원인을 추구하면 모두가 상원일(上元 日)에 본명초례(本名醮禮)를 올리는 뜻에서 나온 것이다. 또 세화 (歲畫), 십장생(十長生) 및 문배(門排), 선녀(仙女), 신장(神將), 천 중절(天中節)의 적부(赤符)는 역시 다 고려에서 전해 내려온 도가 의 행사이다.” 유교 이념이 지배하는 조선시대에도 민간과 궁정에

45）車柱環著, 『朝鮮の道教』，三浦國雄/野崎充彥譯（日本人文書院，1990）, p.409. 
서는 부록 혹은 주술을 사용하여 질병을 치료하는 풍습이 잔존해 있었는데, 이에 관한 대표적인 예로서 단오절의 '천중적부'(天中赤 符), ‘옥추단', ‘옥추단제'(玉樞丹祭) 등의 행사를 들 수 있다.

조선 후기 학자인 홍석모(洪錫謨)가 쓴 『동국세시기』(東國歲時 記)「오월」편에 “관상감에서는 해마다 단오절에 주사(朱砂)로 천 중적부(天中赤符)를 박아 대궐에 올린다. 그러면 대궐에서는 이것 을 문미에 붙였었다”라 하였고, 그 내용은 “五月五日, 天中之節, 上得天祿，下得地福，峘尤之神，銅頭鐵額，赤口赤舌，四百四病，一 時消滅, 急急如律令."(오월 오일 천중절(天中節)에 위로는 하늘이 내리시는 녹(祿)을 받고 아래로는 땅이 주시는 복을 받고 치우신 (虫尤神)의 머리, 쇠로 된 이마, 붉은 입과 붉은 혀의 힘을 얻어 4 04가지의 병이 소멸 될지니 급히 법대로 시행하라)였다. 관상감에 서는 병을 치료하기 위해 '천중적부’를 쓰는 것을 권장하였고, 이 에 궁정의 내의원들 또한 '옥추단'의 풍속을 적극적으로 활성화시 키고자 하였다. 이에 대해서는 『열양세시기』(洌陽歲時記) 중의 “내 의원에서는 음력 6월 토왕일(土旺日)에 옥추단을 만들에 임금께 진상하였다. 이에 임금은 옥추단을 각신(閣臣)들에게 각각 세 개씩 하사하였다”라는 일례를 들 수 있다. '옥추단'은 '태을자금단'(太乙 紫金丹)을 다르게 일컫는 말로서 1497년에 간행된 『신선태을자금 단』(神仙太乙紫金丹)이라는 의서에서는 이에 대해 상세한 설명을 덧붙이고 있는데, 관련 내용에서 언급되는 '옥추단', '태을자금단' (太乙紫金丹) 등의 명칭을 통해 볼 때 의서와 도교가 밀접한 관계 를 지니고 있음을 알 수 있다.

『동의보감』제9권「잡병편」에서는 ‘옥추단’의 제조법이 ‘태을자 금단'과 같으며, '태을자금단'을 다른 말로 '자금정'(紫金錠) 또는 '만병해독단'(萬病解毒丹)이라고도 하고, 이를 독충의 독을 치료하 는데 쓴다고 소개하고 있다. '옥추단'의 제조법에 대해 『증보문헌 비고』에서는 이래와 같이 말한다. “옥추단제(玉樞丹祭)는 의약신에 게 제사를 지내는 것으로, 5월 5일에 내의원에서 제례를 올린다. 이때 음식을 담는 준(樽), 뢰(嘼), 폐(幣), 작(爵)은 곧 풍(雲), 운 
(雲), 뇌(雷), 우(雨)에 대응하는데, 내의원관(內醫院官)이 헌관(獻 官)을 맡는다. 이 외에도 제례의 격식은 내의원에서 주관한다. '옥 추단'제는 의약신에게 제사를 지내는 행사의 일부분이었으며, '풍, 운 뇌, 우'와 관계되는 국가의 제례와 동등한 무게를 지녔다.

『동의보감』에서『구선활인심법』(㺟仙活人心法)에 대한 내용을 여 러 차례 인용하고 있다는 점은 설명이 필요하다. 『구선활인심법』은 명나라 때 주권(朱權)의 저서이다. 주권(朱權)의 자(字)는 구선(臞 仙)이며 호(號)는 함허자(涵虛子), 단구선생(丹丘先生)이고 자호(自 號)는 남극하령노인(南極遐齡老人), 대명기사(大明奇士)로서 명대 개 국황제 주원장의 열일곱 째 아들이다. 주권은 43 대 천사인 장우초 (張宇初)와 매우 우호적인 관계를 가졌는데, 장우초를 스승으로 삼 고 도전(道典)을 공부하였으며 도교의 의례와 이치를 알리는 데 힘 썼다. 주권은 또한 서산구령(西山緱嶺)에 도관을 지었는데, 성조(成 祖) 주체(朱棣)는 '남극장생궁'(南極長生宮)이라는 편액을 하사하였 다. 그는 또한 은둔하여 도학을 공부하는 데 힘썼으며 자경자(自經 子), 구류(九流), 성력(星曆), 의복(醫卜), 황로(黃老) 등의 많은 술 에 능하였다. 『활인심법』(活人心法)은 14 세기 말에 발간되었는데, 명나라 가정(嘉靖) 연간에는 조선안현각본(朝鮮安泫刻本)이 있었다. 『활인심법』 상권에는 치심(治心), 도인법(導引法), 거병연년육자법 (祛病延年六字法), 보양정신(保養精神) 및 보양음식(補養飲食)에 관 한 내용이 포함되어 있다. 또한 하권에는 옥급이십육방(玉笈二十六 方)을 편집하여 수록하였으며 영비십팔방(靈秘十八方) 중의 내용이 가감되어 수록 되었는데, '옥추단'의 내용도 이에 포함된다.

현대에 이르러 한국에서는 덕(德)을 공행(功行)의 신앙이념으로 삼는 토대 위에서 구천응원뇌성보화천존강성상제에 대한 신앙이 크게 성행하고 있다. 20세기 초 증산성사(瞄山聖師:1871-1909)가 해원상생, 보은상생의 법도로 수도하면 정신개벽, 포덕천하, 구제 창생이 실현되어 지상선경이 도래할 것이라는 대도의 진리를 홍포 하였다. 그 후 증산성사의 종통을 계승한 도주(道主) 정산(鼎山:18 95-1958)은 증산성사가 구천대원조화주신(九天大元造化主神)으로 
천하를 대순하다가 인계에 강림하였으며 신통자재(神通自在), 무애 자득(無礙自得) 하시며 40년간 유일무이한 진리를 인계에 선포하 셨고 해탈초신(解脫超身)으로서 보화천존의 제위에 오르셨으니, 삼 계를 통찰하시고 무한무량한 세계를 통할(統轄)하시는 지존지엄하 신 구천응원뇌성보화천존상제라고 선언하였다. 그리고 증산성사를 구천응원뇌성보화천존강성상제로 신앙하는 무극도를 창도하였는 데, 무극도는 후에 태극도로, 1969년 대순진리회로 발전되어 현재 한국사회에서 5 대 종단에 포함되는 교단으로 성장하였다.

대순진리회는 증산성사께서 인세 강림 전 구천대원조화주신이며 화천 후 구천응원뇌성보화천존상제의 위에 임하였다고 신앙하는 종단이다. 즉 증산이 천존상제의 화신이라 믿는 것이다. 이와 연관 하여 대순진리회의 경전인 『전경』(典經)에서는 아래와 같이 이르 고 있다. "상제께서 삼계의 대권을 수시수의로 행하셨느니라. 쏟아 지는 큰 비를 걷히게 하시려면 종도들에게 명하여 화로에 불덩이 를 두르게도 하시고 술잔을 두르게도 하시며 말씀으로도 하시고 그 밖에 풍우·상설'뇌전을 일으키는 천계대권을 행하실 때나 그 외 에서도 일정한 법이 없었도다.”46) 이를 볼 때, 증산성사께서는 능 히 삼계를 주재하시며, 신명을 조화하시고, 천하를 바로 잡으심을 알 수 있는데, 이것은 증산성사가 천존상제의 화신으로 믿어질 수 있는 중요한 근거이다.

이것과는 다르지만 인간이 신의 화신이 되는 신성한 변화를 중 국의 도교에서는 ‘변신'(變神)이라고 일컫는다. 도교의 ‘변신'은 내 련(內煉)을 행할 때나 법술을 행할 시에 도인들이 필히 진입해야 할 특이한 정신 상태로서 이는 자아의 존재를 망각하고, 신(神)의 참된 경지에 들어서서 인신합일(人神合一)을 이루는 것을 의미한 다. “이러한 상황에 이르면 만 가지 사려가 잦아들고 원시(元始)가 곧 내가 되고 내가 곧 원시(元始)가 되어 찬란한 금빛을 발하며 천지 시방을 통제할 수 있게 된다.” ${ }^{47)}$ 즉, 도를 행하는 자가 곧

46)『典經』, 中文版（大巡真理會出版部, 2010), p.95.

47）『道法會元』, 卷八四, 『道藏』, 第29冊, p.344. 
천존이므로 그가 행하는 모든 것은 하늘을 대신하는 것이며, 신 (神)을 대신하여 운화(運化)를 행하는 것이다.

'변신'은 뇌법에 있어서의 극비 공결(功訣)로서 교외(教外)의 사 람들은 이를 잘 알지 못한다. '변신'의 핵심은 의식의 에너지를 운 용하는데 있으며, 존상(存想)의 방법을 통해 스스로 신령(神靈)으 로 화(化)하여 인간이 신과 동일한 경지를 이룸으로써 숭고하고 신성한 경지에 도달하는데 있다. 바꾸어 말하자면, 범인(凡人)의 단계에서 신령(神靈)의 단계로 나아간 후 다시 하늘을 대신하여 일을 행하는 특이한 정신 상태에 진입하는 것이다. 『도법회원』(道 法會元) 권1에서는 아래와 같이 말한다. "변신(變神)의 도는 어떤 것입니까? 스승이 이에 답하기를 '원시(元始)의 조겁(祖劫)인 일기 (一氣)가 진(真)으로 분화하여 내가 곧 원시이고 원시가 곧 내가 되는 것을 일컬어 변신이라 한다.." ${ }^{48)}$ 이러한 상태와 경험 속에서 신령이 신앙자에게 진입하게 되고 신령이 신앙자의 몸과 정신에 머물게 되거나 혹은 신령 자신의 신성함 속에 융화됨으로써 신과 정신이 합치되는 것이다. 그러므로 높은 경지에 이른 자들은 이미 인신의 경계를 넘어서서 근본적인 변화를 이루었다고 할 수 있으 며, 개인과 신성한 실체가 결합되어 신령의 신분으로 만신(萬神)을 부르고 제세도인(濟世度人) 할 수 있게 된다. 변신은 대순진리회의 수도 목적인 도통과 한편으로는 유사한 면이 있다고 보여진다. 대 순진리회에서 도통이란 도즉아(道師我) 아즉도(我郎道)의 경지를 자각하는 것과 연관되어 있는데 여기서의 도는 곧 원시와 유사한 의미로 해석할 수 있기 때문이다. 또한 변신의 “신령이 신앙자에 게 진입하게 되고 신령이 신앙자의 몸과 정신에 머물게 되거나 혹 은 신령 자신의 신성함 속에 융화됨으로써 신과 정신이 합치되는 것"이라는 표현은 대순진리회의 종지인 신인조화와 유사한 의미를 지녔다고도 볼 수 있다.

변신을 이루는 것은 신인합일(神人合一)을 이루는 것이다. 모든

48）『道藏』, 第28冊, p.675. 
각양각색의 법술(法術)에 신이 운용되지만, 신인합일을 이루었을 때 비로소 진정으로 일을 도모할 수 있게 된다. "천지에 신명이 가득 차 있으니 비록 풀잎 하나라도 신이 떠나면 마를 것이며 훍 바른 벽이라도 신이 옮겨가면 무너지나니라" 49 ) 하셨음을 통해 알 수 있듯이 증산성사께서는 신인합일의 개념을 크게 인정하셨음을 알 수 있다. 『전경』에서는 또한 “人為陽, 神爲陰, 陰陽相合, 然後 有變化之道也. 不測變化之術, 都在於神明, 感通神明. 然後, 事其事 則謂之大仁大義也.[사람을 양(陽)이라 하고 신을 음(陰)이라 하는 데, 음양이 상합(相合)을 이룸으로써 변화의 도가 있게 된다. 변화 불측한 술(術)은 모두 신명에게 있으며, 신명과 감통(感通)한다. 그 런 연후에 이러한 일을 가리켜 대인대의(大仁大義)라 이른다]”50) 라 하였다. 이로써 증산성사의 신선관이 매우 확연히 표출되었다 고 보여진다. 증산께서 보시기에 신선을 이루는 것은 신과 인간의 조화를 근본으로 하는데, 조화의 기초는 화합으로서, 신과 인간이 화합을 이룰 때 절대적인 평행을 유지할 수 있으며, 그렇지 않을 경우 조화를 실현하기는 매우 어렵다. 차선근은 “人과 神이 상합 을 하기 위해서는 인존시대이기 때문에 人이 神에게 가는 것이 아 니라 神이 人에게 와야 한다. 따라서 신인상합이 이루어지는 장소 는 神界가 아니라 人界 즉 현세가 된다. 증산은 '마음은 신이 출입 하는 기관이고 문호이고 도로이다.'라고 하여 人과 神이 만나는 접 점이 心이라고 하였다. 心은 人이 가지고 있으니, 神은 心에 의지 할 수밖에 없다”고 한 바 있다.51) 대순진리회가 목적하는 지상신 선실현이 의미하는 것이 사람이 도를 깨닫는 노력을 통해 신의 경 지에 도달하는 것이 아니라 인간의 본질과 천성을 회복하여 이에 상응하는 신과 합일하는 것이라는 점에서 뇌법의 변신과 유사한 점이 있다고 할 것이며 이에 대해서는 추후 연구과제로 남겨둔다.

49)『典經』, 中文版, p.259.

50) 같은 책, p.318.

51）車瑄根, 「近代韓國神仙思想的變容」『道與東方文化』(北京：宗教文化出版社, 2012), p.210. 


\section{九天應元雷聲普化天尊信仰研究}

\section{李遠國}

中國四川省社會科學院・研究員

\section{一、雷法信仰的九宸天尊 \\ 二、九宸高真與雷聲普化天尊}

三、普化天尊信仰的科儀方法

四、韓國的普化天尊信仰

雷法是道教中一門重要的法術, 它以內丹為本, 符咒致用, 融道教 傳統的符箓、咒術、指訣、禹步、氣功、存神及內丹術為一體, 並採 納吸收了儒學修持心法，以及佛教禪學及密教的真言密咒等修法。

自唐宋以來，先有葉法善、豐去奢、鄧紫陽、胡惠超、葉千韶、汪 子華、翟法言、舒虛寂、譚紫霄等高道, 倡雷法于唐代。後有林靈 素、王文卿、張繼先等人，創神霄派於北宋。由於眾多高道的宣導， 以雷神信仰為核心的雷法流行天下，成為道教法門的最高代表。以神 霄、豐猋、清微、天心、正一、上清、靈寶、淨明為稱謂的眾多雷法 盛行社會, 引起世人的廣泛關注，影響頗大。明張宇初『峴泉集』卷一 日：神霄雷霆派，始于玉清真王，而火師汪真君闡之。次而王文卿、 张虛靖、薩守坚等，倡其宗者林靈素、徐神穿、劉混康、雷默庵、萬 五雷、方貧樂、鄧鐵崖、莫月鼎，而派亦衍矣。1）正是在新興道派紛 紛並立、各種雷法盛行天下的歷史背景下, 產生了一大批以雷神崇拜 為核心的道教新神。

1）見『道藏』, 第33冊, 第187頁。文物出版社、上海書店、天津古籍出版社1988年影印本。 


\section{一、雷法信仰的九宸天尊}

兩宋時期的中國社會, 道教雷法盛行於世。雷法的興盛, 推動了雷 神信仰的發展與充實。於是, 出現了一大批主掌風雨雷電、鎮妖伏魔 的神靈。這些道教新神仍然統御在三清聖祖之下。在元始天尊、靈寶 天尊、道德天尊的寶座下邊, 靈寶東華派系以四御, 神霄派則為九宸 天尊, 即祖師玉清真王長生保命天尊, 宗師青華救苦太一定福天尊, 真師九天益等司命保福天莓, 靈師應元定籍真君注命天尊, 玄師保命 化生真君保命天尊, 聖師節度總監真君保生天尊, 寶師保生真君儲祥 天尊，天師掌法主籍真君和豫天尊，神師掌令降命真君吉集天尊。2)

九宸天尊之中, 又以神霄玉清真王为首席主尊。依道经所言, 玉清真王 为元始天尊的小弟。老君曾告诉五雷君等日:昔在劫初, 玉清神母元君, 是浮黎元始天尊之后, 长子为玉清元始天尊, 其第九子位为高上神霄玉清 真王长生大帝, 专制九霄三十六天、三十六天尊, 为大帝统领, 元象主握 阴阳,以故雷霆之政,咸隶焉。3)

考六朝道經『上清大洞真經』中所載諸神中有高上神霄玉清王，這當是 他首見於經典。至北宋徽宗時，神霄派道士遂將其與扶桑大帝相融合， 構造了一位新的尊神。『高上神霄紫書大法』序日：玉清神母生子八人。 長日南極長生大帝，亦號九龍扶桑日宮大帝，亦號高上神霄玉清真王， 一身三名，其聖一也。”這位一身三名的玉清真人凝神金關，思念世間 一切眾生三災八難, 又見九幽泉豐一切罪魂受報, 生死往來如旋車輪, 即諧元始上帝，懇請九霄寶籙，願以其神通，憫救三界一切眾生。元始 上帝即以高上神霄玉清真王長生護命秘法傳付下世。一部三卷，上隱萬 天之禁，中隱神仙萬年之法，下明治人治鬼保國寧家之道。4)

九宸天尊次位為青華救苦太一定福天尊, 亦稱東華青華大帝。他就

2）見『高上神霄玉清真王紫書大法』卷四, 『道藏』第28冊第596頁。

3）見『紫微立都雷霆玉經』, 『道藏』第1冊第750頁。

4）見『道藏』第28冊第557頁。 
是道教神系中出入地獄, 解厄賜福的大神太一救苦天尊。據『太一救苦 護身妙經』載，在東方長樂世界有大慈仁者太一救苦天尊，化身如恒沙 數，物隨聲應，或住天宮，或降人間，或居地獄，或攝群邪，神通無 量, 功行無窮, 尋馨救苦, 應物隨機。三界萬靈眾生, 若遇危厄苦 難, 時遭疾疫, 病痛總綿; 波浪所驚, 魚龍欲傷; 值雷霹靂, 風雨驚 怖; 六親不和, 兄弟乘疏; 兵火作謪, 風雨不調; 邪精鬼賊, 妄來所 傷; 胎孕不安, 臨產鋇難; 頻遭枷鎖, 屢受冤牢; 流滞地獄, 未得托 生，但當存思，念誦聖號，便得解脫，出離余圄。5)

自宋代以後, 道教中人對太一救苦天尊的崇拜十分流行, 並深入民 間, 得到朝廷的推重, 從而成為“六御”之一。『道門科範大全集』卷二 四曰：“金關虛無三清上帝，吴天六御宸尊。”6) 即在原有的“四御”之上 增補了南極長生大帝玉清真王、東極青華太一救苦天尊。救苦天尊的 聖相多變, 或 “足躡蓮花, 圓光照耀, 手執柳枝淨水, 九頭獅子, 左右 從隨”; 或“化一女子，身著火錦䘽衣，披發跣足，躡於蓮花，手執金 劍, 圓光照耀，九頭獅子口吐火焰，繞於身形。”7) 由此可見，太一救苦 天尊拯救亡魂，超度眾生的功德甚大。

九宸天尊的第三位是九天益等司命好生可韓君丈人保福天尊，即青城 丈人朱陵度命天尊, 居青城可韓宮。朱陵度命天尊的信仰始于唐代。李 沘撰『九天使者廟碑並序』日：開元十九年八月二十一日，降明旨日：青 城山丈人廟, 盧山使者廟, 宜準五訔真君廟例。抽德行道士五人, 焚修 供養, 仍委所管, 揀擇灼然道行者, 安置真年, 名申所由, 敕置廟使, 內供奉將使者真圖，建立祠廟，拜章醮，行道設齋，使大供道觀。8）其餘 九宸諸師亦各有主司，分掌法教。

記載雷霆尊神的『高上神霄玉清真王紫書大法』, 出於北宋政和年間。 時徽宗皇帝崇信道教, 在全國範圍大力扶植和推行道教。他寵信道士魏

5）見『道藏』第6冊第 182 頁。

6）見『道藏』第31冊第812頁。

7）見『道藏』第6冊第183頁。

8）見『盧山太平興國宮採訪真君事實』卷六，『道藏』第32冊第683頁。 
漢津、徐神鳻、劉混康、張繼先、林靈素、王文卿等，推重神霄派道 法。命天下皆建神霄萬壽宮，于京師開神霄籙壇，傳籙散符，宣神霄法 於天下。政和七年(1117年)二月，在林靈素的策劃下，徽宗宣稱“青華 帝君”夜降宣和殿，授他“帝誥、天書、雲籙”，遂命道士二千余人集合 於上清寶籙宮，由林靈素宣諭其事，並命京師吏民皆受“神霄秘籙”。於 是林靈素搜集九天秘書、龍章鳳管、九等雷法，集成玉篇進上。其後徽 宗欲得雷書金經全部，收入『道藏』，但求訪不得。於是，林靈素假借 “玉華天尊”奏告上帝，上帝遣玉女以印相授的名義，造“神霄嗣教宗師 印”、“都管雷公印”等，連同『雷書』五卷進奏，遂得全集。

其時古『度人經』本一卷, 徽宗時亦以神霄瓊室秘藏的名義增造六十 替。此外, 尚有『高上神霄玉清真王紫書大法』、『高上神霄玉清秘篪』、 『高上神霄真王說五方天中好生不殺頌』、『神霄東極華堂妙濟經科』、『 高上神霄真王長生大帝降生記』、上清玉書真符照驗諸記』、冬祀天真 降臨示現品記』等雷經，“神霄內府所存三洞四輔，有自古以傳者，或多 見於世。有歴劫未傳禁秘寶經，一千二百卷，分為六等，一十二品，列 為上中下三卷，藏于東西華堂。”9）這说明在政和、宣和年間，以神霄府 秘藏名義編造的神霄經可能多達上千餘卷。

今本『高上神霄玉清真王紫書大法』共十二卷, 撰人不詳。從內容文 字看, 應為宋時神霄派道土所作。全書前有『高上神霄紫書大法序』 稱 : 高上神霄玉清王凝神金献, “憫念世間一切眾生，三災八難，一切 眾苦, 九幽泉豐, 一切罪魂, 受報緣對, 浩劫相求, 無量眾苦, 不舍書 夜，生死往來，如旋車輪。”故詣元始上帝金關之下，請『神霄真王秘法 』一部三卷。10）據此，可知本書原僅三卷，即今『道藏』本前三卷，約出 於北宋末。其餘九卷當系南宋增益。

需要說明的是, 正是在這部重要的神霄經典中, 並無普化天尊的聖 位。這似乎說明普化天尊的信仰其時尚未彰顯, 時至南宋, 因白玉蟾 的推演，普化天尊的信仰方大興於世。

9）見『道藏』第32冊第638頁。

10）見『道藏』第 28 冊第557頁。 


\section{二、九宸高真與雷聲普化天尊}

有關雷聲普化天尊的記載, 首見於『無上九霄玉清大梵紫微玄都雷 霆玉經』。11）經文假託為神霄玉清真王長生大帝傳授，主要論述神霄雷 法。內稱：神霄玉清真王統領元象，主握陰陽，掌管九霄三十六天雷 霆之政。雷霆者，乃天地之樞機，能賞善罰惡，司生司殺。大而生 死，小而榮枯，非雷霆無以主其政。12）故下界安國撫民，消災求福等 事，皆隸屬雷霆之政。經文說：“吾為高上神霄玉清真王長生大帝，其 次則有東極青華大帝，九天應元雷聲普化天尊，九天雷祖大帝，上清 紫微碧玉宮太乙大天帝，六天洞淵大帝，六波天主帝君，可韓丈人真 君，九天採訪真君，是為神霄九宸。”13）明朱權襲用了這一說法，亦日： “九宸，日長生大帝、青華大帝、普化天尊、雷祖大帝、太乙天帝、洞淵大 帝、六波帝君、可韓真君、採訪真君，即元始九氣化生也，故號九宸上 帝。代天以司造化，主宰萬物。”14）這九位大神為神霄雷法之本尊，總號 “雷霆九宸高真”。顯然，『雷霆玉經』所載九宸高真已與『紫書大法』所言 九宸天尊略有不同，這當是宋代神霄派神系的另一傳承。

九宸高真中的長生大帝、青華大帝、丈人真君，已見於『高上神霄玉 清真王紫書大法』, 其餘則為新出之神。如雷祖大帝, 居九天雷霆中 宮。『太乙真雷霹靂大法』中主法神尊即為太乙雷祖大帝，面赤菓色， 兇惡相，至尊至嚴，不可犯也。15)

後來的道經謂雷祖大帝亦即斗母、天母。『祈雨心章式』載法師奏 章，其曰：上奏法主九天雷祖聖德巨光天母摩利支天紫金妙相皇君御 前，日宮太陽帝君聖前，月府太陰皇君聖前。16）斗母形象非常奇特，或

11）見『無上九霄玉清大焚紫微玄都雷霆玉經』一卷，撰人不詳，似為北宋道士所造。

12）見『道藏』第 1 冊第752頁。

13）見『道藏』第 1 冊第752頁。

14）見朱權『天皇至道太清玉冊』卷五，『道藏』第36冊第404頁。

15）見『道法會元』卷一三三，『道藏』第29冊第649頁。 


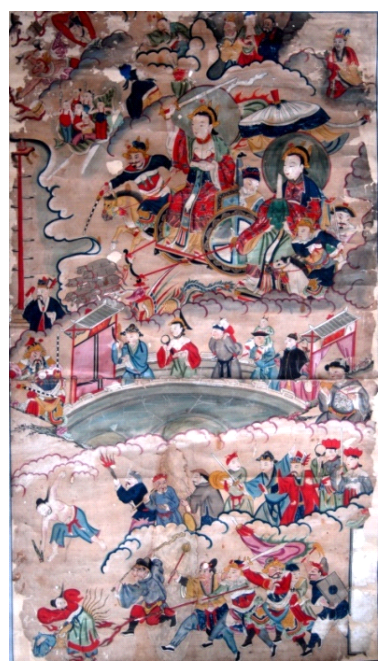

〈圖 1〉斗姆出巡圖 （清代繪畫李遠國藏）

顯形為二臂，或顯形為八臂：斗母紫光天后 摩利支天大聖，化身四頭八臂，頭正面天神 相，頭左面豬，頭右面鬼，頭後面獅相。八 臂，兩手分掌日月; 一手執戟，戟上有黃 幡，上有金字，为九天雷租大帝; 一手握 劍，一手持印；一手拿金繩，一手持弓，一 手持箭。坐在由七只豬拖拉的车辆。17)

九天採訪使應元保運妙化真君，亦稱九天 真王、火鍊真人、南上真君, 出現較早, 至 逰於魏晉時已有。據『太上三天正法經』稱 : 九天真王與元始天王，俱生始息之先。『南 唐降現真圖記』日：真君佩九元之劍，帶五 帝伏魔之印、九天真王之印，乃天中貴神， 所以分真宅靈，下鎮洞天福地，利澤邦家， 䊺紳信禮，士庶欽仰，靈既昭彰。18）『九天應元雷聲普化天尊玉樞經』 亦言：此神本為太陽九龍皇君，後受天尊符命，為九天採訪使者，其 職司雷霆之道，總御四序，控制五行。19)

自唐宋以來，以江西盧山為祖庭，九天採訪使者崇拜的風潮盛行於 江南。唐玄宗时，命建使者祠於盧山。殿宇中塑採訪使居中，左右侍 立金童、玉女、靈官各二，六丁六甲各六。殿內兩壁畫上清太微二十 四位真人，殿外兩壁左畫十二溪女，右畫九江水帝、三江大王。皆倣 吳道子之本，相貌奇古，精神晸動。殿之左翼供三官大帝,殿右翼供四 聖真君。20）盧山自建九天使者廟以後，福及生靈，香火鼎盛，並形成 了供奉神靈的群眾性“蓮花會”誓歲以此日同會於此，祈年穀，禳庇

16）見『道法會元』卷九十『先天一焉雷法』, 『道藏』第29冊第375頁。

17）見姚複莊『玉樞經錀』卷二十注，『藏外道書』第4冊第787、788頁，巴蜀書社1994年版。

18）見『盧山太平興國宮採訪真君事實』卷一，『道藏』第32冊第662頁。

19）見『道藏』第 1 冊第752頁。

20）見『盧山太本興國宮採訪真君事實』卷一，『道藏』第32冊第663頁。 
瘦。21）其後, 歷代朝廷累加賜封, 多廣宮宇, 使九天採訪使者的信仰 長盛不衰。22)

下面講講九天應元雷聲普化天尊, 他的神威非常重大。至匹天應元 雷聲普化天尊玉樞寶經』問世, 雷聲普化天尊便成為雷霆主宰大神, 而 取代了神霄玉清真王的職權。23）經文假託為雷聲普化天尊所說，宣揚 一種方便法門，即持誦天尊聖號。天尊言：一切眾生，天龍鬼神，一 稱吾名, 悉使超渙。但冥心默想作是念, 言九天應元雷聲普化天尊, 或一聲, 或五七聲, 或千百聲, 吾即化形十方, 運心三界, 使稱名 者, 咸得如意。24)

這種持誦法門, 簡潔易曉, 人人皆可習作, 故很快在社會上推廣。 南宋建炎元年(1127年), 有吳人周舉自京師歸鄉裏。是時战乱纷呈, 群盜四起。忽遇道人日：子明日死於兵難, 若能誦十字經, 可以免 死，解冤延壽。周舉㻊地以請，道人日：九天應元雷聲普化天酎，乃 十字經也。周舉得其神授, 堅心默識。明日果遇强盜, 亟誦前號。聲 未絕口, 而雷聲大震。群盜驚走，逐得脫難。25）這裏明白記載了持誦 “十字經”靈驗與功效, 亦為『玉樞寶經』出於北宋的一條證據。

『玉樞寶經』以雷聲普化天莓信仰為中心, 詳盡地描述了雷聲普化天 尊的神格、職司、權能, 宣稱他是總司五雷, 普化群生, 賞善罰惡之 神, 講述了祈禳雷法、重玄至道。書中告訴我們, 雷聲普化天尊又號 九天貞明大聖, 主治玉霄府, 統三十六天內院, 中司東西華台, 玄官 妙閣, 四府六院及諸有司, 各分曹局, 所以總司五雷, 天臨三界者 也。若或有人欲學道成仙, 超度祖先, 欲釋三災, 當命正一道士, 或 自同親友於樓觀、於家庭，於裏社，釂水饋花，課誦此經，或一過， 三五過, 乃至數十百過, 即得神清氣爽, 心廣體胖。凡所希求, 悉應

21）見『盧山太平興國宮採訪真君事實』卷一，『道藏』第32冊第664頁。

22）見『盧山太本興國宮採訪真君事實』卷三，『道藏』第32冊第675頁。

23）『玉樞寶經』一卷，撰人不詳，出於北宋徽宗時期。

24）見『道藏』第 1 冊第758、759頁。

25）見『盧山太平興國宮採訪真君事實』卷七，『道藏』第32冊第700頁。 
其感。26)

他居住在三十六天之上，手舉金光如意， 宣說『玉樞寶經』。以清靜心弘大願, 以智能 力而伏諸魔, 總司五雷, 運心三界, 群生 父, 萬靈師。27）恩被十方, 德沾萬匯, 當令 萬願以克從。凡所希求, 悉應其感。28)

經文一論“至道”，二言“氣數”。內稱：“道 者以誠而入, 以默而守, 以柔而用。用誠似 愚, 用默似訥, 用柔似拙。夫如是, 則可與 忘形, 可與忘我, 可與忘忘。入道者知止, 守道者知謹, 用道者知微。能知微則慧光

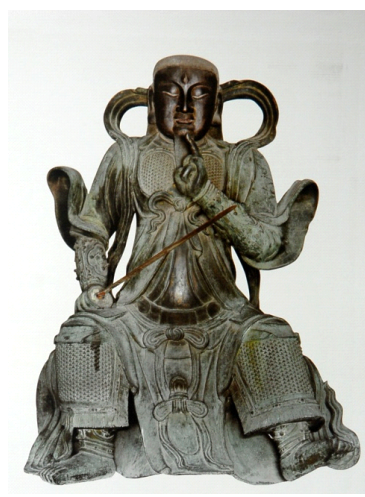

<圖 2>普化天尊像 (明代銅像北京東茯䎁藏) 生, 能知謹則聖智全, 能知止則泰定安, 泰定安則聖智全, 聖智全則 慧光生, 慧光生則與道為一, 是名真忘。惟其忘而不忘, 忘無所忘, 無可忘者, 即是至道。”29）認為人之稟受不同謂之氣，智愚清濁謂之 數; 數系乎命, 氣系乎天。學道之士若為氣數所固, 天命所梏, 則不 得真道。經文又述消災解厄之法, 謂凡遇三災九厄, 可依法持誦經 文, 若默念普化天尊之號, 即有諸神消災解厄; 若歸命此經, 可以長 生。

依道書所言，雷聲普化天尊乃玉清真王的化身。『九天應元雷聲普化 天尊玉樞寶懺』日：“我租師由神霄而閪化。恭惟九天貞明之大聖，玉 清真王之化身, 分形十方, 運心三界, 拯衆生之苦惱, 挈下土之沉 淪。三十六天，天天歸主宰之權。千五百劫，劫劫運慈悲之化。”“恭惟 九天應元雷聲普化天尊, 為群生父, 為萬靈師。”30)

關於雷聲普化天尊的形象，『九天應元雷聲普化天尊玉樞寶經集注』

26）見『道藏』第 1 冊第758、789頁。

27）見『九天應元雷聲普化天尊玉樞寶懴』, 『道藏』第3冊第550頁。

28）見『雷霆玉極宥罪法懺』, 『道藏』第3冊第552頁。

29）見『道藏』第 1 冊第759頁。

30）見『道藏』第3冊第549、550頁。 


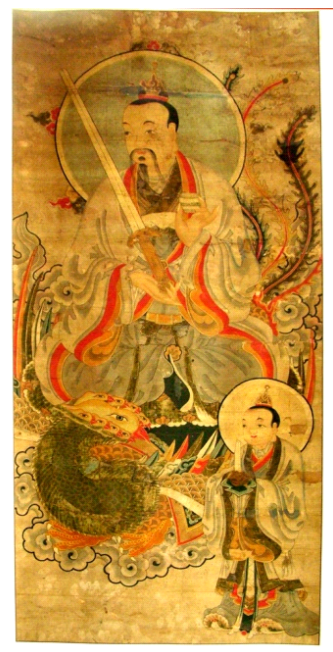

<圖 3>普化天尊像 （清代繪畫四川原道博物館藏）

卷上曰：“天尊所坐九鳳丹霞之展，手舉金光 明之如意, 琅風清微，綺雲郁麗。”31）所謂“九 鳳”, 即九頭朱鳳。今所存清代雷聲普化天尊 畫像中, 雷聲普化天尊正是坐在一頭九頭朱 鳳之上, 左手掐 “三山訣” 而捧淨杯, 右手放 置臍前，掌心托劍，法相慈悲端莊。

卷下又曰：“九天普化君，化形十方界。披 發騎麒麟, 赤腳躡層冰。手把九天氣, 婣風 鞭雷霆。能以智慧力, 攝伏諸魔精。濟度長 夜魂，利益於眾生。”姚複莊注：“是天尊既 以明威者, 欲化天下之仁, 而以披發騎麒麟 者示之。”32)

這是明代的一幅 神像畫, 圖面中央 者為雷聲普化天尊, 披发露额, 跨坐在麒麟 之上, 赤腳, 右手持鐵鞭高揚, 象徵“啸風鞭 霆” ; 左手指 “訣”, 中指尖發射出九色光, 此 即“手把九天氣”之意，代表天尊號令雷霆。 所謂“九氣”者，為萬物之根。

雷聲普化天尊周圍為雷部所粶雷公、電 母、雨師、風伯及十大元帥。十大元帥造型 奇特, 英武威猛, 頗難辨識。經初步考辦, 有鄧伯溫元帥、辛漢臣元帥、張元伯元帥、 王善元帥、監生高元帥、殷郊元帥、馬勝元

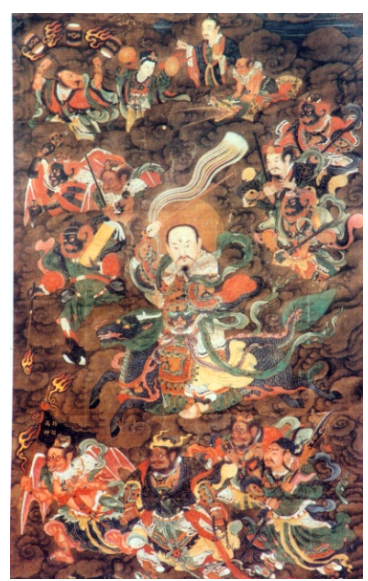

<圖 4>雷聲普化天尊像 （明代繪畫美國私人藏）

帥、苟章元帥、畢環元帥、關元帥。這些神將多出於兩宋之際，且多 為雷部諸神。如鄧伯溫、辛漢臣、張元伯，道書稱之為雷霆三帥。

31）見『道藏』第2冊第573頁。

32）見姚複莊『玉樞經錀』卷二三，『藏外道書』第4冊第803頁。 


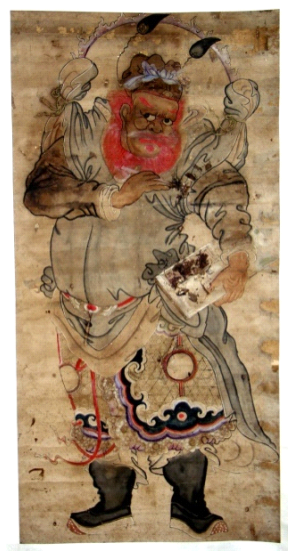

〈圖 5〉鄧伯溫像 （明代繪畫李遠國藏）

據白玉蟾所言, 三帥的淵源甚古, 乃上古帝王 伏犧、黃帝之後。伏犧有二子, 長子祝融為南斗 火官, 次子郁光即鄧伯溫。黃帝本為雷神之子, 而辛漢臣、張元伯正是黃帝之後裔。33）姚複莊『玉 樞經錀』卷二十注：一雷公相，肉角，紅發，青 面，蘭身，肉翅，手足鳳爪，三目，金環，身掛 金縷紅裙飛仙帶, 右手雷槌, 左手雷鑽, 九天運 令雷王鄧伯溫。一鐵嘴, 銀牙, 蘭身, 火帶, 襆 頭, 綠袍, 㿝鞾, 左手雷簿, 右手火筆, 制官 形, 九天掌令雷王辛漢臣。一肉頭, 紅發, 青 面，鳳嘴，蘭身，肉翅，手足鳳爪，金環，身掛 青縷, 紅裙飛帶, 右手雷斧, 左手雷鑽, 或右手 執旗，左手執文檄，九天行令雷王張元伯。34）此三帥主掌雷霆三部， 故應時降世，神威甚大。

監生高元帥, 即九天監生大神。此大神右手杖劍, 左手託盤, 內有 一小孩。『文昌應化延嗣妙應經』云，九天監生高元帥，招神攝風，篤 生佳胤。”

殷郊元帥，亦名上清武春猛吏太歲、地司猛吏太歲、地司太歲大威 德神王。『三教搜神大全』卷五曰：殷郊元帥乃為紂王之子，生即為肉 球包裸, 而遭妲已堍害, 棄遺於郊, 烏鴉蔽日, 白鹿供乳, 適申真人 經過, 將劍剖球, 得一嬰兒, 即抱歸水濂洞, 求乳母賀仙姑哺而育 之。法名金叮奴, 正名金哪吒。又緣其棄郊之故, 乳名殷郊。後修真 得道，於天妃八寶洞中得黃鈛、金鐘，收伏 “媲神鴉將”; 又應真人令 往掃帚山，征討十二強人，“乃十二喪門哭鬼骷髏神。帥即往盡戴之， 懸首掛頸胸而回。真人日 : 此骨非他也, 能助陣, 一敲鬼哭神驚, 人 頭昏悶手軟, 不戰自退。真人遂令其助周武王伐紂, 元帥率雷震子

33）見『道法會元』参八二『雷霆三帥心錄』，『道藏』第29冊第328、329頁。

34）見『道法會元』卷九八，『道藏』第29冊第423頁。 
等, 勇為前鋒, 顯威殺敵, 並親斬妲已以報 親仇。玉帝聞其有孝慈之德, 又有斬妖之 勇, 乃敕封為地司九天游奕使至德太歲殺伐 威權殷元帥。關於他的形象, 或“青面束發, 項中作䯽, 紅髮䰅, 朱衣, 大神頂上一骷 髏，項下九骷髏，左手持金鐘，右手執黃 鈛，乘九頭金牛。35）或“青面，青身，金冠， 朱發，緋袍，皇緣絞紮腰間，上左手托日， 右手托月；下右手鋮斧，下左手金鐘。項上 懸掛十二骷髏，自午方五色雲中至。”36）但其 基本特徵為項、額皆帶有骷髏, 顯威猛忿怒 像，這一形象在道教護法元帥中甚少。

左伐魔使苟元帥, 右伐魔使畢元帥, 乃執 守雷門元帥。『三教源流搜神大全』謂荷元帥

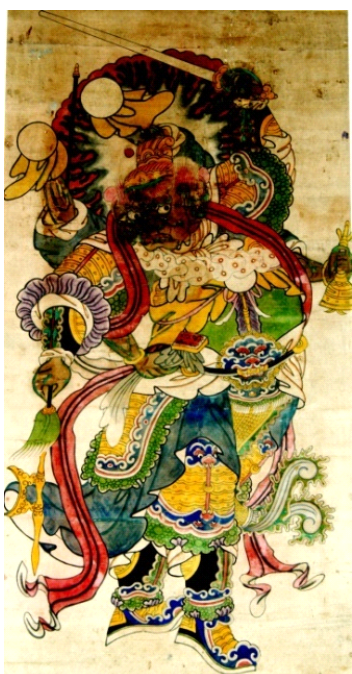

<圖 6>殷郊像 （清代繪畫李遠國藏） 為雷門布鼓之神，與畢帥共五方事，往來行天，剪幽明中邪魔鬼惡。 又言畢元帥敕掌十二雷庭，輔立天上帝，誅瘟役鬼，上管天地潦固， 下紏群魅出沒，中擊不仁不義等輩。

紏伐靈官王天君，又稱 “南極火雷赤心忠良猛吏王元帥”。據道經所 言，王靈官本名王善，宋徽宗時淮陰地方奉祀的小神。後薩守堅真人 燒了他的廟宇, 於是他懷恨在心, 暗中追隨十二年, 欲其失戒而施行 報復, 但終不能得, 遂誠心歸降薩守堅。玉皇大帝封其為“先天主 將”, 主司天界、人間紏察之職。其造像一般為紅臉虫須，金甲紅袍， 三目怒視，左手執風火輪，右手舉鞭。『道法會元』卷二四二日：“赤 面，紅鬚髮，雙目火睛，紅袍，綠靴，風帶，左手火車，右手金鞭， 狀貌躁惡。”這位赤心忠良的王元帥, 後來便成為整個道教所尊奉的護 法神，他鎮守在幾乎所有的道教宮觀。

35）見『道法會元』卷三七，『道藏』第 29 冊第7頁。

36）見『道法會元』卷二四七，『道藏』第30冊第521頁。 


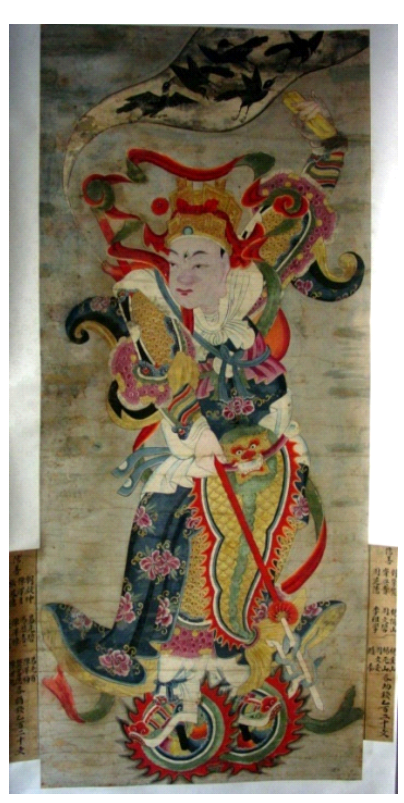

<圖 7>馬元帥像 （清代繪畫李遠國藏）

魁神靈官馬元帥，又稱“靈官馬元帥”、 “華光天王”、“華光大帝”、“馬天君”等, 為道教護法天神。據『三教源流搜神大全』 卷五稱, 原是至妙吉祥化身, 以五團火花 投胎于馬氏金母，面露三眼，妙樂天尊， 訓以天書，凡風雷龍蛇䤋鬼安民之術，麼 取不精。乃授以金磚三角，變化無邊。遂 奉玉帝敕, 以服風火之神, 而風輪火輪之 使；收百加聖母，而五百火鴉為之用；降 烏龍大王而犲之翼，斬揚子江龍而福於 民。屢曆艱險，至忠也。帝授以左印右 劍，掌南天門事,民妻財子祿之祝，百吒百 應，雖至巫家冤枉祈禱之宗，悉入其部， 直奏天門，雷庽風行焉。

趙元帥, 即趙公明, 又稱“高上神霄玉府 大都督”等, 為道教護法大神。『道法會元』 卷二三二日：元帥姓趙, 名朗一, 一名昶, 字公明。終南山人。秦時 避亂山中, 精修至道, 功行圓滿, 被玉帝旨召為神霄副帥。其服色頭 戴鐵冠，手執鐵鞭者，面色黑而影䰅者，北氣也。跨虎者，金象也， 元帥上奉天門之令, 策役三界, 巡察五方, 提點九州, 為直殿大將軍 北極侍御史。逮祖天師修煉大丹, 飛神奏帝, 請威猛神吏為之守護。 由是元帥上奉玉旨, 充正一玄壇元帥。部下有八王猛將者, 以應八卦 也。有六毒大神者, 以應天繁、地慜、年急、月慜、日繁、時慜也。 五方雷神、五方猖兵, 以應五行。二十八將, 以應二十八宿。天和地 合二將, 所以象天門地戶之闔辟。水火二營將, 所以象春生秋繁之往 來。驅雷役電, 呼風喚雨, 除瘟剪崇, 保病欀災, 元帥之功莫大焉。 至如公訟冤抑，神能為之解釋。公平買賣，求財宜，利和合，但有至 公至正之事, 可以對神言者, 禱之無不如意。其形象為鐵色面, 圓 
眼，黑影䰅，戴鐵襆頭，黃抹額，披金甲，皇罩袍，綠靴，右手執二 十四節鐵鞭，左手執鐵索，有黑虎隨身。37)

溫瓊元帥，又稱 “溫太保”。相傳其為浙東溫州平陽縣人，字子玉。 其母張氏夢“南方日輪”而有娠, 遂生太保。長大有志, 武勇敢為, 時 隨唐朝郭子儀出戰平盜, 身為先鋒, 白刃未嘗傷體。後入泰山東獄廟 供職，精進三年，化為猋府太保，“訔帝遂詔為地府冥司急取人案大典 者，人之生死，皆由所掌。”38）因助葉法善降魔，而名震西蜀。兩宋之 際，因高道吳思敬、張虛靖、王宗敬、吳道顯、柳伯期等大倡“地祇溫 太保秘法”於世，對溫太保的信仰遂流布南方各地。其形象非常威猛， 身長九尺餘，青面，青手，獠牙，唇紅，發赤，眉須赤，金眼，猙 獰，寒紫巾方頂，著鷹花綠袍，金束帶，黑吊敦靴，豹皮棍，手執金 骨朵，捉崇仗劍。39)

朗靈上將關元帥，即關才才，又稱“蕩魔真君”、“伏魔大帝”、“關聖帝 君”、“鄲都朗靈首或魔關元帥”、“三界伏魔大帝神威遠震天尊關聖帝 君”，簡稱“關帝”，俗稱為“關公”、“關老爺”。關帝信仰是由三國時蜀 國名將關犲衍化而來。因與吳國作戰而死，追湓為壯繆侯，並立祠以 祀。北宋徽宗時, 因張虛靖天師召請, 禳除澥池之蛟怪並顯聖於帝 前，封為“崇寧至道真君”。明清以來，關帝信仰已不直於教門，既列 入國家祭祀要典, 又為民間供奉之神。關聖帝君既是武神, 又是財 神, 具有司命祿、佑科舉、治病除災、驅邪辟惡、誅罰叛逆、巡察冥 司、庇護商賈、招財進寶之職能, 且法力無邊。關帝信仰如此普遍, 關帝廟數不勝數, 遍及天下。關於他的形象, 依道經所載: “元帥重霖 色面, 鳳眼, 三车須, 長髯一尺八寸, 天青結巾, 大紅朝服, 玉束 帶, 㿝朝靴, 執龍頭大刀, 有赤寃馬隨。常用喜容, 如䤋攝, 怒容, 自雷門而至。”40)

37）見『道藏』第30冊第446頁。

38）見黃公瑾『地祗上將溫太保傳』, 『道藏』第18冊第91頁。

39）見『道法會元』卷二五四，『道藏』第30冊第560頁。

40）見『道法會元』二五九，『道藏』第30冊第588頁。 
以雷霆十帥為主, 再加上龐、陶、劉、秦、趙等天君及閃電神、助 風神，一共二十四員催雲助雨護法天君，合稱雷部二十四天君。『封神 演義』載殷朝輔相聞仲化為九天應元雷神普化天尊, 率領雷部二十四 員, 催雲助雨護法天君, 興雲布雨, 萬物托以長養, 誅逆除奸, 善惡 由之禍福。他乘坐墨麒麟, 使陰陽鞭, 此鞭原是兩條蛟龍化成。其屬 下雷部天君正神名諱：鄧天君忠，辛天君環，張天君節，陶天君榮， 龐天君洪，劉天君甫，苟天君章，畢天君環，秦天君完，趙天君江， 董天君全，袁天君角，李天君德，孫天君良，柏天君禮，王天君變， 姚天君賓，張天君紹，黃天君庚，金天君素，吉天君立，余天君慶， 閃電神, 助風神, 荘芝仙。

從南宋以來，雷聲普化天尊信仰大行於世，『玉樞寶經』廣為刊發。 嘉定十二年(1219年)正月五日, 白玉蟾派楊伯子遞書函彭耜, 告知天 庭已正式予餘神職，並囑其刊雷經傳世。

在中國民間中, 雷聲普化天尊的信仰非常普遍。『歷代神仙通鑒』卷 四謂黃帝得道升天後, 封為九天應元雷聲普化真王, 居雷城之中, 真 王之前有雷鼓三十六面，三十六神司之。凡行雷之時，真王親擊本部 雷鼓一聲, 即時雷公雷師發雷聲也。『封神演義』載：雷部正神聞仲, 因 其證修大道, 貞烈可憫, 元始天尊特敕封為九天應元雷聲普化天尊之 職，率領雷部二十四護法天君。『西遊記』中亦有雷聲普化天䡤應孫悟 空之請, 差鄧、辛、張、陶諸師率領雷部眾真, 隨大聖下凡施法。經 過這些文藝小說的宣染，民眾對雷聲普化天尊的崇拜更加深入人心。

\section{三、普化天尊信仰的科儀方法}

作為一種民眾的宗教信仰, 它都需要借助各種儀式與方法, 來實施 體現。當人們在神聖的殿堂中, 點香祈禱, 叨首禮拜, 人神之間的交 流開始感應; 當法師足踏禹步, 手掐印訣, 誦經持咒, 舉行一場禳災 
祈福的法會時, 人們更是領受著神靈的賜福。於是, 各種各樣的科儀 與功法應運而生發, 因需而演化。這裏介紹的就是一些雷霆的科儀方 法。

雷霆謝過設醮儀是一套祈福謝過的科儀。所謂“謝過”, 就是吒首神 靈，跪拜悔過，承認錯誤, 表示慊意。『明真科』日：“信向之士，心口 相應，舍香禮願，已徹諸天：生罪死對，靡不釋然。”只要“屈折禮 拜，吒頭自持”，自可達到“意盡精誠”和“自然感徹”的境界。道教謂人 生有非常多的過錯，從而導致各種災禍的發生。於是道教廣開謝罪悔 過、解冤釋結的法門, 普度天人。

齋醮是道教對其崇拜儀式的傳統稱呼，俗稱 “道場”。是道士修道行道的重要內容。道教創 立齋醮儀範, 其目的主要有二。一是為修道, 二是為通神。道教齋醮儀式具有複雜的結構。 它由各種獨立的科儀組成, 每個科儀又都具有 特定的神學意義和作用。例如 ${ }^{『}$ 先天斛食濟煉幽 科』, 就是由“煉度”、“濟幽”和“斛食”三儀組成 的大型儀式，每次演習時間長達四小時。演荀 此儀就是運道士一己之神氣, 合二象之生津, 煉化亡靈之枯骸, 使之超度入聖。每個科儀又 由具有獨立意義的儀式元組成，例如：升壇、 發爐、署職、唱方等等, 而許多種科儀組合在 一起, 形成為具有一定規模的儀式群, 即齋醮 法會。例如儀式過程需歷時九天的九皇金篆大 齋、三天的下元黃籙大齋等等。所有的獨立科

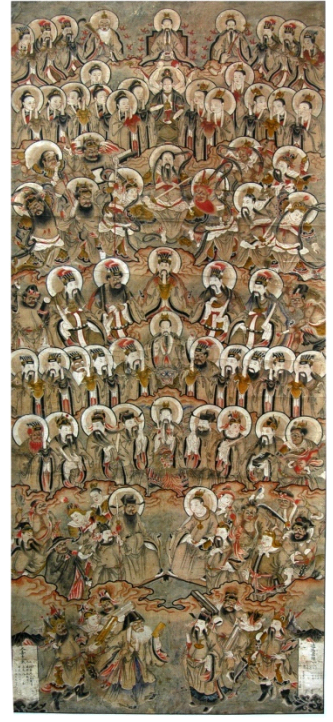

〈圖 8> 道正宗師圖 （清代繪畫李遠國藏） 儀組合在一起, 以達到某時某處舉行大型齋醮法會的神學要求。

雷霆謝過設醮儀, 是由神霄派法師主持的齋醮法會。法會中法師踏 罡步虛, 在醮壇上邊贊誦邊步行。旋繞上宮, 稽首行禮, 散花燒香, 嘯詠洞章，唯正身前向，臨目內視，存見天尊在高座上，注念玄真， 使心形同。行三獻法事，法師稱法位，謹重誠上啟三清上聖、十極高 
真、萬天上帝、日月星宿、省府曹僚、地水訔瀆城隆社令, 醮筵內外 一切真靈, 謝其玄恩盛德。然後宣贊詞, 並與醮官頓首恭, 灑陳呈 獻。法會中尚要“請聖”, 法師與臨壇官眾等, 虔誠請天地諸神光臨。 諸神駕臨，須舉行“降聖”儀式，鶴駕臨軒，三界眾真，如儀朝禮。朝 禮既周, 請升醮席。醮官上香設拜, 並進酒。要進表, 道土將書寫信 眾祈願的表文送達天庭, 祭告上帝, 祈眾聖光臨醮壇, 賜福延齡, 先 靈受度。根據行儀的不同目的，表奏上帝的內容不同。途至天宮的表 文在壇場上由表白法師宣讀後, 即送至焚表場所焚化。壇場法眾誦 經, 以誦經來幫助修道行持。白玉蟾稱誉誦經，就是“代天尊而演說經 教, 體大道以引接浮生”, 包含有傳教弘法的意義。

九天應元雷聲普化天尊玉樞寶懺, 是道士為信徒悔罪祈福的懺儀及 懺悔文式。首先由道士率信徒, 禮拜讚頌 “九天應元雷聲普化天尊”之 神威功德 ; 其次懺謝自身罪業, 並願志心歸命三寶及諸天尊神靈, 祈 求赦罪賜福。法事如儀。其后, 依序诵唱, 志心的命禮三清, 志心歸 依道寶經寶師寶, 當願衆生普上法橋, 無有障礙。道場衆等人, 各運 心禮懺如法。臣等虔恭, 志心朝禮, 的命九天應元雷聲普化天尊。畢 各一拜, 皈命九天應元雷聲普化天尊, 九聲九拜。步虛, 每一禮一 拜, 志心的命禮, 南極長生大帝統天元聖天尊, 東極青華大帝太一救 苦天尊, 九天可韓丈人朱陵度命天尊, 九天雷祖大帝除災濟物天莓, 碧玉宮太一大天帝保制劫運天尊，六天洞淵大帝伏魔上上太乙天尊， 六波天主帝君普施法潤天尊, 九天採訪使真君應元保運妙化天尊, 九 天應元府卿師使相一切仙真, 雷部真仙諸司官屬。禮足各長跪, 的命 懺悔。41)

『九天碧潭雷禱雨大法』是奉浮黎元始天尊、昊天玉皇上帝、後土皇 地祗、九天雷祖大帝、九天應元雷聲普化天尊為主法的一大雷法, 其 下标雷神萬萬眾。這些雷公形象奇特, 皆肉角, 鷹喙, 金睛, 雙翅, 龍爪, 手足風裙仙帶。凡新雨時, 雷公各為黑面, 噴雨行事; 祈晴

41）見『九天應元雷聲普化天尊玉樞寶懺』, 『道藏』第3冊第549、5 50頁。 
時, 雷公各為赤面赤身, 噴火行事; 新雪時, 雷公各為白麵白身, 噴 雪行事。法師役雷運雷, 先須行功打坐, 結鍊內事, 依時辰下工夫, 以接天地之喣。

以上所述皆為道教法師所曶煉施行, 對普通民眾與信徒而言, 可選 擇一些簡單易曉、操作方便的修養法。如天民梳頭法、天民出入法、 天民齋粥法、天民沐浴冠帶法、天民解衣法、天民臨臥法、天民遇疾 服藥法、天民履穢入暗法、禳惡夢法、安五藏法、安耳鳴法、去災厄 法、還神法、明目法、自解憂愁法等, 均適合於一般人慣用, 故可謂 之“方便法門”。

方便法門以其簡潔易行而廣為流傳，其中最為重要的是持誦法門， 即道者虔誠如一, 常年持久的誦念天尊聖號, 可達功德圓滿之境界。『 玉樞寶經』謂普化天尊以此法門，化世人之患，澄世人之濁，廣度天 人。即在日常生活中, 時常誠心持誦寶經, 念誦九天應元雷聲普化天 尊寶號，則可安魂息靈，靜心和脈。凡有刑沖克戰，動用行藏皆凶繁 者, “歸命此經, 誦咒焚香告符, 則一切厄難, 皆能解釋。”此外, 或 沉疔㽽疾緾身, 或婚合臨盆有難, 或鬼精妖莩做崇, 皆當誦經焚符, 則身安而無不吉利。由此可見此經, 有不可思議之功德, 如同經中所 言： “承天尊力, 有此靈通。出入起居, 佩帶經此, 眾人所欽, 鬼神所

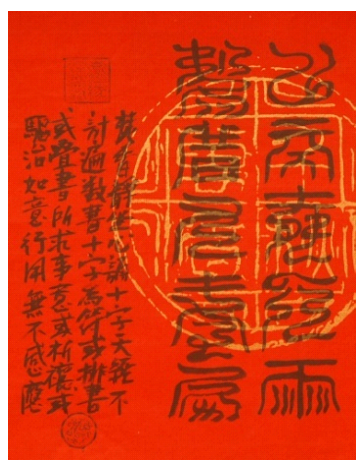

〈圖 9〉十字天經符 (李遠國繪)

畏, 遇諸險難, 一心稱名九天應元雷聲普化 天尊，悉得解脫。” 42 )

這種持誦法門被稱為“十字天經法”, 這十 個字這是雷祖聖號。按『玉樞寶經』記載:持誦 十字天經可得十大功效：(1)靜心和脈, 人物 安寧，身心康泰，延年葐壽；(2)解除苦難， 免災消厄，潛消口舌，永息官司；(3)治病祛 疾, 遠離瘟疫, 除一切病, 解諸種痛; (4)和 婚夫妻, 護胎保命, 䢪嬰衛房, 子嗣永延;

42）見『道藏』第1冊第759、760頁。 
（5)驅崇辟邪, 收魅伏妖, 安寧魂魄, 清靜身心 ; (6)超亡度魂, 七租 九先, 脫離陰間, 得以生天; (7)水陸通暢, 出入平安, 招財納祥, 四 海聚福；（8)風調雨順，四季和適，五穀豐收，富饒安寧；(9)真空無 染, 與道為一, 進德無魔, 升舉有日; (10)消除惡業, 成就善根, 得 見天尊, 證驗功德。凡好道之士, 或有心學道而未遇明師, 或身體抱 恙魂嵬不安, 或命運多外流年多滯, 或遇官符口舌, 或犯方隅神棂, 或求婚合子息, 或家有鬼精, 或遇邪詛, 或有瘟賟, 或出行遁隱, 或 祈請禱雨，或欲免三災九横，或懺悔罪㩐等，皆可諷誦『玉樞經』及專 心持誦十字天經，自有感應，災害悉得消除。

普化天尊以此方便法門濟世度人，誦念聖號可擺脫饑寒、疾疫、刀 兵、九幽、刑殺、克害、貪天、傷殘、孤䕗、禍害、劫慜、災慜、歲 棂、破敗、冤枉、官災、牢獄、天厄、地厄、水厄、五方厄、四時

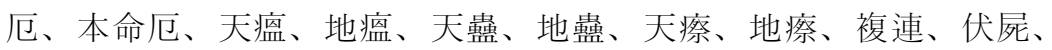
故氣、鬼注、天災、火災、水災等等災難。概而言之, 誦念 ${ }^{\circledR}$ 玉樞寶經 』及九應元雷聲普化天尊寶號的功德, 主要有廣度天人, 靜心和脈, 解除厄難，治病祛疾，護胎合婚，驅崇辟邪，超亡度魂，潛消口舌， 永息官司，人物安守，水陸本康，風調雨順，免災消厄等，而有不可 思議的驗證。不僅如此, 還可達真空無染的地步。故深受民眾歡迎, 廣泛流行, 其各種注本釋本多達二十余種, 成為宋元以來道教重要文 獻之一。

\section{四、韓國的普化天尊信仰}

自『玉樞寶經』的問世，很快即傳播至日本、韓國等國家。韓國安東 浚博士『論韓國醫學與道教之關係』一文, 論述了歷史上高麗朝廷與北 宋徽宗朝的交流, 認為高麗賏䢪靑牛予徽宗, 徽宗回賜『玉樞寶經』 
等, 可推定神霄雷法於其時已傳入高麗。並謂高麗睿宗十三年(1118) 七月，宋徽宗派遣楊宗立、秉義郎、曹誼、杜舜舉、成湘迪、陳宗 仁、藍茁七名醫師出使高麗, 傳授了兩年的醫學, 由此推測出從那時 起中國道教醫學開始在高麗悄然傳承，傳入高麗的道教醫學當是以神 霄派『玉樞經』為中心的治療法。通過政和年間與宋的交流，高麗道教 以福源宮為中心發展起來，並受中國道教的影響，供奉玉皇上帝、太 上老君、雷聲普化天尊。朝鮮初期，在掌管道觀的國家機關昭格署選 拔道流時，必須誦讀『禁壇』、『靈寶經』、『延生經』、太一經』、王樞 經』、『眞武經』、『龍王經』，並按照“『王樞經』八節酬所讀。”43)

延及明清，雷聲普化天尊的信仰在日本、韓國等國家已十分普及。 我們在許浚主編的『東醫寶鑒』中, 可以看到道教對韓國醫學的重要影 篰。『東醫寶鑒』以「內景篇」、「外形篇」、「雜病篇」、「湯液篇」、「針尒 篇」構成，其特徵正是以道教的教理為依據來揭示醫學本質。「内景篇」 運用道教的精氣神說, 強調了在病之先養生的意義, 「雜病篇」述說了 瘟疫和邪崇，蜔毒項目，努力提出實質性病因和治療方法。但是，在 此過程中高麗時代符咒式道教醫學的痕跡並沒被完全掃光，有時也因 現實的需要而被利用，其代表性例證可舉「雜病篇」中的“催生符”和“玉 樞丹”。催生符和出產有關，“玉樞丹”用於治療鬼崇和巫蛊，這些雖然 多少具有神秘色彩, 用現在的眼光看可說是一種精神療法。許浚完成『 東醫寶鑒』以後，把醫學領域擴大到了巫醫們的領域- - 瘟疫治療，晚 年留下了『新纂辟瘟方』、『辟疫神方』、『諺解痘瘡集要』等著述。許浚 的持續性成就和不解的努力閃耀在韓國醫學史上，但其背後是有著深 受力圖革新道教符咒治病術的朝鮮內丹學派影響的儒醫們的道教養生 思想在做支持的，這一點是不能忘記的。44)

其時『玉樞經』在朝鮮社會廣泛傳播。民間多持誦玉樞經咒，運用符 籙，治病驅邪，保胎護命。據『韓國冊板目錄總覽』記載，已有綾州、 同福、寧辺三種『玉樞經』刻本傳世。其中同福版刊于隆慶四禩庚午(15

43）見安東浚「論韓國醫學與道教之關係」、『道學研究』總第五期(2005年6月)。

44）見安東浚「論韓國醫學與道教之關係」。 
$70)$, 是由“全羅道同福地無等山安心寺開版”。䆟辺版刊于英租九年(1 733), 是“妙香山普賢寺“這座佛教的寺院刊印。這本朝鮮刻本的『玉 樞經』卷首載有雷聲普化天尊等四十七人的神像圖, 經文收白玉蜳、張 真君、張天君、呂純陽等四人的注釋。45)

在李能和所著『朝鮮道教史』中，第二十二章「道教與盲人」說: “按道 家者流, 有術數、占驗之一派。朝鮮盲人, 以卜為業, 是屬此派也。” “讀經以驅逐者，盲人之業也。而盲所讀有佛家之書(如千手八陽等 經), 有道家之經。然而千手八陽, 乃間誦而非專讀。專讀之經, 『玉 樞經』是已。”還說，盲人“道流僧”讀經之時，用朱砂在槐黃紙上寫下從 “九天應元普聲普化天尊” 到“素車白馬大將軍” 總共四十八神將的名 號，貼在躺有患者的房內，打鼓、讀經四到七日，然後請神將降臨， 捉邪鬼埋於地下。顯然盲人“道流僧”的這種咒術, 與道教符籙派的咒 術毫無差別,並直接援自『玉樞經』道法。第二十四章「年中行事與道教」 又有如下記錄：“今我巷俗尚有直星吉凶，度厄之法，而於正月十四日 為之。此雖年中行事之一事, 而究其所自則, 蓋出於上元日行本命醮 禮之義也。又有歲畫、十長生、及門排、仙女、神將、天中節之赤 符，亦皆高麗遺傳之道家行事也。”即使到了以儒教為支配理念的朝鮮 時代，民間和宮中還殘存著通過符籍或者咒術來治療疾病的風俗，代 表性的事例有端午節“天中赤符”、“玉樞丹“、“玉樞丹祭”等活動。

朝鮮後期學者洪錫謨的『東國歲時記』中的「五月」篇曰：“觀象監朱砂 拓天中赤符, 進於大內貼門楣, 以除弗祥。卿士家亦貼之。其文曰:五 月五日, 天中之節, 上得天祿, 下得地福, 虫尤之神, 銅頭鐵額, 赤 口赤舌, 四百四病，一時消滅，急急如律令。”觀象監推行“天中赤符” 謀求治病，宮中的內醫院也不甘落後，推行進御“玉樞丹”風俗。『洌陽 歲時記』曰：“內醫院以季夏土旺日，祀黃帝，制玉樞丹進御。內賜閣 臣三枚。”說的正是此事。“玉樞丹”是“太乙紫金丹”的別名，在1497年 刊行的『神仙太乙紫金丹』醫書中有詳細的介紹，從“玉樞丹”、“太乙紫

45）見車柱環著、三浦國雄/野崎充彥譯『朝鮮の道教』第409頁，日本人文書院1990年版。 
金丹”等名稱可以推測出它與道教有關聯。

據『東醫寶擥』卷九「雜病篇」介紹說，“玉樞丹”的製作方法和“太乙紫 金丹”一樣，“太乙紫金丹”又名“紫金錠”,也做“萬病解毒丹”，是用來 治療蛊毒的。“玉樞丹”便是在此基礎上添加一兩雄黃和五錢朱砂，然 後用金䈌包起而成的。製作“玉樞丹”一事，正如『增補文獻備考』所说： “玉樞丹祭，祭始醫藥之神，五月五日行於內醫院。饌實樽眐幣爵，同 風、雲、雷、雨。獻官內醫院官。”具有祭禮的格式, 由內醫院主管。 這裏，“玉樞丹”祭作為祭祀醫藥之神活動的一部分，與對“風、雲、 雷、雨”行祭的國家祭禮有著同等的地位。

需要說明的是，『東醫寶鑒』中多處徵引“臞仙活人心法”。『睢仙活人 心方』為明代朱權所撰。朱權字臞仙，號涵虛子、丹丘先生，自號南極 遐齡老人、大明奇士，明朝开国皇帝朱元璋第十七子。與四十三代天 師張宇初友善，拜之為師，研曶道典，弘揚道教義理。曾于西山緱嶺 創建道觀，成租朱棣賜額“南極長生宮”。隱逸學道，托志沖舉，自經 子、九流、星曆、醫卜、黃老諸術皆具。『活人心法』刊於 14 世紀末， 明嘉靖年間即有朝鮮安泫刻本。卷上為養生法, 內容包括治心、導引 法、祛病延年六字法、保養精神及補養飲食等。卷下輯錄玉笈二十六 万及加減靈秘十八力，其中即有“玉樞丹”。

正是在這種以德為功行的信仰理念下，九天應元雷聲普化天尊姜聖 上帝的信仰在當代韓國應運大興。20世纪初賏山圣师(1871-1909)弘 布了若以解冤相生和报恩相生的法理修道，就能实现精种开辟、布德 天下、救济苍生而最终来临地上仙境的真理。此后，继承甑山圣师之 宗统的道主鼎山(1895-1958)向大众公布了如下内容：潧山圣师以九 天大元造化主神的身份大巡天下，降于人界，用四十年的时间神通自 在、无碍自得地向人界宣布了有一无二之真理, 此外, 甑山以解脱超 身登于普化天尊的帝位，因此他是统察三界，统辖无限无量世界的至 尊至严的九天应元雷声普化天尊上帝。由此，道主鼎山创立了将甑山 圣师信仰为九天应元雷声普化天尊的无极道。后来无极道改名为太极 道，1969年将太极道的名称又被改为大巡真理会，发展成韩国五大宗 
团之一的大教团。

大巡真理会相信甑山圣师降世之前的身份为九天大元造化主神, 化 天后临于九天应元雷声普化天尊的帝位, 即天尊上帝化身为㬝山。大 巡真理會『典經』告訴我們：“上帝可隨時隨地施展三界大權。若想止住 傾盆大雨, 則令其眾從徒, 在火爐旁時用火球在空中劃圓圈, 時而用 酒杯劃圓圈：時而用言語行事。此外, 欲招風雨、霜雪、雷電等的天 界大權而行事，或其他各種情況下皆無定法。”46）粗山聖師之所以能夠 主宰三界, 調化神明, 匡扶天下, 这就是能相信天尊上帝化身为㬝山 圣师的重要依据。

与大巡真理会不同, 中国的道教将人变为神的神圣变化一化身说为 “变神”。道教的“變神”, 是指在內煉或施法時候, 道人必須進入一種 特異的精神狀態, 即化去自我的存在, 轉變化身成為神真, 人神合 一, “到此之時, 萬慮俱寂, 元始即我, 我即元始, 金光燦爛, 掣動天 地十方。”47) 也說是說, 道者就是元始天尊, 就是太上老君, 就是雷聲 普化天尊, 因此, 他的所作所為都是替天行道, 代神運化。

“變神” 是雷法中的至秘功訣, 故教外之人難以明曉。其要害在於運 用意識的力量, 存想自己變化成為神靈, 人神無別, 達到一種非常崇 高神聖的境界。換而言之, 即由凡人的層次上升為神靈的層次, 從而 進入一種代天行化的特異精神狀態。『道法會元』卷一日：“或問變神之 道如何? 師曰: 元始祖劫, 一氣分真, 我即元始, 元始即我, 此即謂 之變神。” 48 ）在這種狀態與經驗中, 神靈整個地進入了信仰者, 居停在 他身體、精神之中, 或將他融入了神靈自己的神聖性質中, 與神的精 神混合一體。於是, 高道們已經跨越了人神之間的界限, 完成了根本 的轉變, 把個人與神聖實體結合起來, 從而可以神靈的身份感召萬 神, 濟世度人。变神与大巡真理会修道目的的道通有相似的一面。因 为大巡真理会的道通意味着悟到道即我, 我即道的境界, 并且道可以

46）見『典經』中文版第95頁，大巡真理會出版部2010年7月版。

47）見『道法會元』卷八四，『道藏』第29冊第344頁。

48）見『道藏』第28冊第675頁。 
解释为接近原始的意思。此外, “神靈整個地進入了信仰者, 居停在他 身體、精神之中，或將他融入了神靈自己的神聖性質中，與神的精神 混合一體”的內容與大巡真理會宗旨之一的神人造化有相似的一面。

變神化身, 即達神人合一。各種各樣的法術都有神, 只有神人合一 才能圖謀施行。對此神人合一觀念, 瞄山聖師表示了高度的認同。他 說 : “天地之間充滿神明, 縱然弱小草茎, 離神則枯 ; 遍泥之牆, 離神 則塌。”49) “人為陽，神為陰，陰陽相合，然後有變化之道也。不測變 化之術, 都在於神明, 感通神明。然後, 事其事則謂之大仁大義也 。”50）所謂“陰陽相合”, 也就是“神人合一”, 也就是“變化之道”。至 此, 甑山聖師的神仙觀已表達得相當透徹。在他看來, 實現神仙的思 想依據是人與神的調化, 調化的基礎是和諧, 神和人絕對要保持本 衡, 不然調化是難以實現的。車瑄根先生指出: “為了神人合一, 神應 該靠近人類, 神人合一的地方應該在現世。㬝山認為心是神出入的器 官、門戶、道路。神人合一的地點應該在心。而心是人擁有的，神只 能依靠心。”51）因此在大巡真理會成為地上神仙, 並不是人通過努力悟 道, 達到神的境界, 而是恢復人的本質或天性, 达到与相应的神合一 的境界, 因此这与雷法有相似的地方。对于本次研究的不足之处, 希 望有后续研究。对其希望有后续研究。

49）見『典經』中文版第259頁。

50）見『典經』中文版第318頁。

51）見車瑄根，「近代韓國神仙思想的變容」，金勳主編，『道與東方文化』第210頁，北京： 宗教文化出版社2012年版。 


\section{【参考文献】}

『典经』，中文版，大巡真理会出版部，2010。

『玉樞寶經』一卷, 撰人不詳, 出於北宋徽宗時期。

『无上九霄玉清大梵紫微玄都雷霆玉经』, 卷一, 撰人不详。

『道藏』, 文物出版社、上海书店、天津古籍出版社, 1988年影印本。

『九天应元雷声普化天尊玉枢宝经』, 『道藏』, 第 1 册。

『紫微玄都雷霆玉经』、道藏』, 第1册。

『九天应元雷声普化天尊玉枢宝经集注』, 『道藏』, 第2册。

『九天应元雷声普化天尊玉枢宝忓』, 『道藏』, 第3册。

『雷霆玉极宥罪法忏』, 『道藏』, 第3册。

『道门科范大全集』, 『道藏』, 第6册。

『太一救苦护身妙经』, 『道藏』, 第6册。

黄公瑾, 『地祇上将温太保传』, 『道藏』, 18册。

『高上神霄玉清真王紫书大法』, 『道藏』, 第28册。

『道法会元』, 『道藏』, 第29册。

『道門科範大全集』, 卷二四, 『道藏』, 第31冊。

『庐山太本兴国宫采访真君事实』, 『道藏』, 第32册。

张宇初, 『岘泉集』, 卷一, 『道藏』, 第33册。

朱权, 『天皇至道太清玉册』, 卷五, 『道藏』, 第36册。

安东浚, 「论韩国医学与道教之吴系」, 『道学研究』, 总第五期, (2005 年6月)。

姚复庄, 『玉枢经钥』, 卷二十注, 『藏外道书』, 第 4 册, 巴蜀书社, 1994年版。

车瑄根, 「近代韩国神仙思想的变容」, 金勋主编, 『道与东方文化』, 宗 教文化出版社，2012年版。

车柱环著, 三浦国雄/野崎充彦译, 『朝鲜の道教』, 日本人文书院, 1990 年版。 


\section{구천응원뇌성보화천존(九天應元雷聲普化天尊) 신앙 연구}

\section{리 웬구어(李遠國)}

중국사천성 사회과학원

뇌법은 도교의 중요한 법술로서 당송(唐宋)이래 매우 흥했는데, 북송의 임영소 등이 신소파(神霄派)를 개창한 이후에 도교 법문을 대표하는 영역이 되었다. 그로부터 각종의 뇌법이 천하에 성행하 였고, 도교에는 새로운 뇌신들이 거듭 나타나게 되었다. 그 대표적 인 것이 뇌법신앙의 구진천존(九宸天尊)인데, 이 아홉 천존들은 도 교의 최고신인 삼청성조(三清聖租)의 통치 하에 있는 것으로 간주 되었다.

『옥추보경』은 북송 때 탄생하였는데 이 경전이 세상에 널리 발 간되어 구천응원뇌성보화천존에 대한 신앙이 형성된 것은 남송 시 기 백옥섬(白玉蟾) 이후이다. 『옥추보경』은 구천응원뇌성보화천존 의 법문(法門)을 선양하기 위한 방책으로 천존의 성호를 부를 것 을 권장한다. 법문을 염송하는 것은 매우 쉽고도 간단하여 누구나 할 수 있었으므로 사회적으로 크게 확대되었다. 특히 『봉신연의』 와『서유기』와 같은 문예소설에 뇌성보화천존이 등장함으로 해서, 민중들은 뇌성보화천존을 더욱 널리 숭배하게 되었다. 현재도 중 국의 민간에서 이 신격에 대한 신앙은 매우 보편적이다.

구천응원뇌성보화천존은 옥청진왕(玉清真王)의 화신(化身)이다. 뇌성보화천존은 시방에 그 형체를 나타내고, 중생들을 고뇌로부터 구제하고 이끈다. 36 천을 주재할 권능이 있으며, 자비로운 모습으 
로 모든 겁에 응한다. 또 뇌성보화천존의 주변에는 뇌공(雷公), 우 사(雨師), 풍백(風伯)을 비롯한 십대원사(十大元帥)와 등백온원사 (鄧伯溫元帥), 신한신원사(辛漢臣元帥) 등의 신장들이 보인다. 이러 한 신장들은 양송(兩宋) 시대에 출현하였으며 대다수가 뇌부의 제 신들이다.

뇌성보화천존 신앙을 구현하기 위한 재초 의식에는 천지 제신 (諸神)이 강림하기를 청하는 뇌정사과(雷霆謝過)와 죄를 뉘우치고 복을 비는 참의(懺儀) 또는 참회문식(懺悔文式) 등이 있다. 이런 법식들은 매우 전문적인 것이고, 일반인들에게는 법문을 염송하는 간편한 방법인 십자천경법(十字天經法)이 널리 퍼졌다. 즉 늘 경건 한 마음으로 천존의 성호를 오랫동안 염송하게 되면 공덕원만(功 德圆滿)의 경지에 도달할 수 있다는 것이다. 『옥추보경』은 민중의 세계에 깊은 영향을 끼치고 광범위하게 알려져 그 주해나 주석본 만도 이십여 종에 이르렀고 송원 이래의 핵심적인 도교 문헌의 하 나로 자리매김하였다.

『옥추보경』은 일본과 한국 등지에도 급속히 전파되었다. 한국에 는 고려시대에 신소뇌법(神霄雷法)이 전해졌는데, 특히 고려 예종 13년(1118년) 7월에 중국 도교 의학이 고려에 전승되었을 때의 도교 의학이 『옥추보경』을 위주로 한 치료법이었다. 그리고 그 흔 적은 조선의 허준이 주편한 『동의보감』에서도 찾아볼 수 있다. 조 선의 민간에서는 많은 사람들이『옥추보경』을 송독하였고 거기에 수록된 부록(符籙)을 운용하였으며 이로써 병을 몰아내고 잡귀를 물리쳐 생명을 지키기를 바랐다.

현대 한국에서는 구천응원뇌성보화천존강성상제에 대한 신앙이 크게 성행하고 있으니, 그 종단이 바로 대순진리회이다. 대순진리 회는 증산 성사께서 인세에 강림하시기 전에 구천대원조화주신이 며, 화천 후 구천응원뇌성보화천존상제의 위에 임하였다고 신앙한 다. 즉 증산이 천존상제의 화신이라 믿는 것이다.

이것과는 좀 다르지만, 인간이 신의 화신이 되는 신성한 변화를 
뇌법에서는 '변신(變神)'이라고 부른다. 변신은 내련(內煉)을 행할 때나 시법(施法)시에 도인들이 필히 진입해야 할 특이한 정신 상 태로서, 자아의 존재를 망각하고 신진(神真)으로 변화하여 인신합 일(人神合一)을 이루는 것을 의미한다. 이러한 변신은 대순진리회 의 수도 목적인 도통과도 한편으로는 유사한 면이 있다고 생각된 다. 대순진리회가 목적하는 지상신선실현이 의미하는 것은, 사람이 도를 깨닫는 노력을 통해 신의 경지에 도달하는 것이 아니라 인간 의 본질과 천성을 회복하여 이에 상응하는 신과 합일하는 것이라 는 점에서 뇌법의 변신과 유사한 점이 있다고 할 것이며 이에 대 해서는 추후 연구과제로 남겨둔다.

주제어 : 대순진리회, 신, 신명, 신장, 신관념, 유형, 전경, 구천상제

() 투 고 일 : 2013년 8월 31일

(a) 심 사 기 간 : 2013년 10월 16일 29일

(0) 게 재 확 정 일 : 2013년 11월 19일 